\title{
Paleomagnetism of the Chinle and Kayenta Formations, New Mexico and Arizona
}

\author{
DAVID R. BAZARD AND ROBERT F. BUTLER
}

\author{
Department of Geosciences, University of Arizona, Tucson
}

\begin{abstract}
Paleomagnetic data were obtained from 22 sites (6-10 samples/site) in the Upper Shale Member of the Chinle Formation, 43 sites in the Owl Rock Member of the Chinle Formation, and 35 sites in the Kayenta Formation. Themal demagnetization and data analyses indicate that within-site dispersion is an important criterion for selecting sites which retain a high unblocking temperature characteristic remanent magnetization (ChRM). Site-mean directions define at least four antipodal polarity zones within each member/formation, suggesting the ChRM was acquired soon after deposition. Fifteen site-mean virtual geomagnetic poles (VGPs) from the Upper Shale Member of the Chinle Formation yield an early Norian paleomagnetic pole position of $57.4^{\circ} \mathrm{N}, 87.8^{\circ} \mathrm{E}\left(K=60, A 95=5.0^{\circ}\right)$. Eighteen site-mean VGPs from the Owl Rock Member of the Chinle Formation yield a middle Norian paleomagnetic pole position of $56.5^{\circ} \mathrm{N}, 66.4^{\circ} \mathrm{E}\left(K=183, A_{95}=2.6^{\circ}\right)$. Twenty-three site-mean VGPs from the Kayenta Formation yield a Pliensbachian pole position of $59.0^{\circ} \mathrm{N}, 66.6^{\circ} \mathrm{E}\left(K=155, A_{95}=2.4^{\circ}\right)$. Combined with paleomagnetic poles from the Moenave Formation and the Shinarump Member of the Chinle Formation, these data record $\sim 30 \mathrm{~m}$.y. of North American apparent polar wander (APW) within a regional stratigraphic succession. During the Camian and Norian stages of the Late Triassic, Chinle poles progress westwand. During the Hettangian through Pliensbachian stages of the Eariy Jurassic, the pattem of APW changed to an eastward progression. Even after correction for $4^{\circ}$ clockwise rotation of the Colorado Plateau, a sharp comer in the APW path ( $J 1$ cusp) is resolved near the pole from the Hettangian/Sinemurian $(200 \mathrm{Ma})$ Moenave Formation $\left(59.4^{\circ} \mathrm{N}, 59.2^{\circ} \mathrm{E}\right)$. Amongst other implications, the sharp change in the APW path at the Jl cusp implies an abrupt change from counterclockwise rotation of Pangea prior to $200 \mathrm{Ma}$ to clockwise rotation thereafter.
\end{abstract}

\section{INTRODUCTION}

Several methods of constructing apparent polar wander (APW) paths have resulted in differing interpretations of North American APW during the Late Triassic and Early Jurassic. Although the concept of an APW path is simple, evaluation of individual paleomagnetic poles, models of path geometries, and averaging techniques introduce complications. Recent interpretations of North America's APW path have employed various criteria for selecting paleomagnetic poles [e.g., Irving and Irving, 1982; May and Butler, 1986]. Typically, a set of criteria involving quality of data, reliability tests, and precision parameters is used to make selection uniform. Some studies have used a time window averaging technique to produce a smooth APW path geometry [Irving, 1977; Van Alstine and DeBoer, 1978; Irving and Irving, 1982]. This technique is intended to reduce noise but may smooth meaningful details related to actual plate motion [Gordon et al., 1984; May and Butler, 1986]. As an alternative, May and Butler [1986] constructed an APW path using selection criteria which exclude noise associated with poorly defined paleomagnetic poles while retaining details of APW path geometry.

Another approach to APW construction is to employ a model of plate motion. The arcuate shape of hotspot tracks and fracture zones imply that lithospheric plates move for time intervals $>10-20$ m.y. about fixed Euler poles. Using this model, Gordon et al. [1984] proposed an APW path composed of small circle arcs of paleomagnetic poles, with each arc resulting from plate motion about a single paleomagnetic Euler pole (PEP). A synthetic APW path can be produced from the predicted plate motion trajectories. However, a synthetic APW path also may exclude details of plate motion that are implied by actual data.

Effects of different methods of APW path construction are pronounced for the Late Triassic-Early Jurassic of North

Copyright 1991 by the American Geophysical Union.

Paper number $91 \mathrm{JB} 00336$.

$0148-0227 / 91 / 91 \mathrm{JB}-00336 \$ 05.00$
America. The time-averaging technique of Irving and Irving [1982] produces a sinuous APW path geometry (Figure 1a), while the PEP model of Gordon et al. [1984] yields a cusp shaped geometry ( 31 cusp) located at a more westward longitude (Figure 1b). The path resulting from May and Butler's [1986] analysis (Figure $1 b$ ) also includes a Late Triassic-Early Jurassic cusp extending farther west than the APW path of Irving and Irving [1982]. These differences in Late TriassicEarly Jurassic APW paths affecl geologic interpretations including initiation of central Atlantic seafloor spreading, paleolatitudes of tectonostratigraphic terranes, and deformational regimes along the Cordilleran margin [Gordon et al., 1984; May and Butler, 1986; May et al., 1989].

Unfortunately, the large confidence limits on many Late Triassic-Early Jurassic paleomagnetic poles hamper evaluation of these interpretations. The poles from the Chinle, Wingate, and Kayenta formations were by-products of early magnetostratigraphic studies [e.g., Reeve and Helsley, 1972; Steiner and Helsley, 1974]. While providing valuable magnetostratigraphic information, improved resolution of the APW path, and foundations for future work, these poles have large confidence limits and thus do not allow clear resolution of APW path interpretations.

To better resolve this critical portion of the North America APW path, we present three paleomagnetic poles determined from Late Triassic and Early Jurassic red beds of the south. western United States. The units studied and methods used were designed to minimize errors associated with paleomagnetic pole determination. These well-defined paleomagnetic poles allow evaluation of the Late Triassic-Early Jurassic portion of the North American APW path. Furthermore, these data support the geometry of the J1 cusp predicted by the PEP model and provide further constraints for geologic interpretations based on Mesozoic paleomagnetism.

\section{REgIONAL TECTONICS AND GEOLOGY}

The formations sampled in this study are red beds of the Colorado Plateau and adjacent regions. These Late Triassic and Early Jurassic red beds were deposited on the craton edge, 


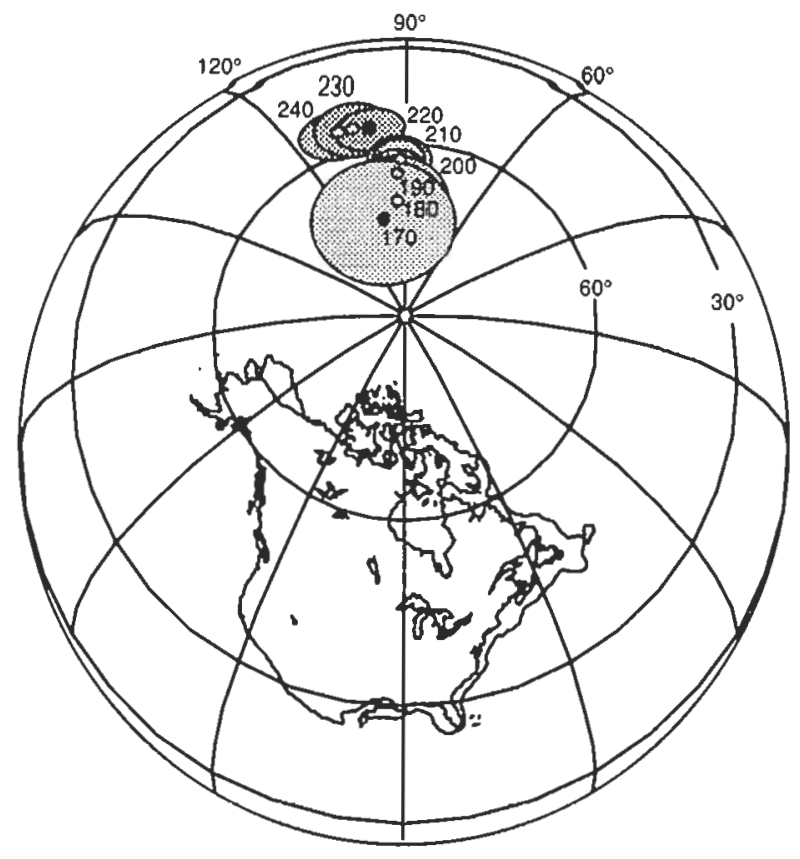

(a) Irving and Irving (1982)

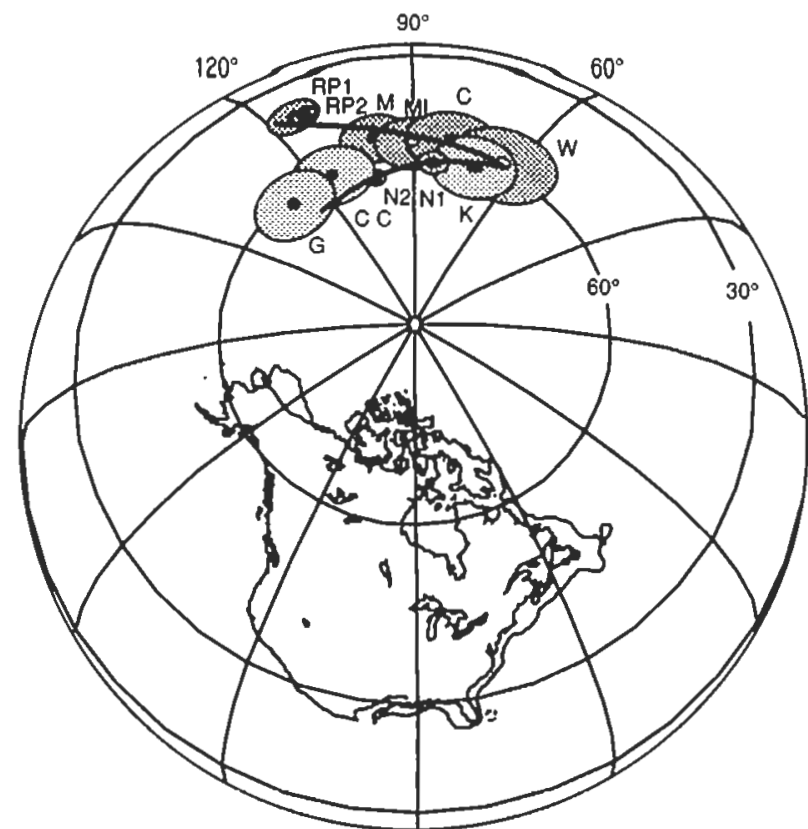

(b) May and Butler (1986)

Fig. 1. Triassic-Middle Jurassic apparent polar wander (APW) paths for North America. (a) Paleomagnetic poles calculated using a $30 \mathrm{Ma}$ sliding window [Irving and Irving, 1982]. Each pole is surrounded by its $95 \%$ confidence limit (shaded area) and ages of poles are given in Ma. (b) APW path of Gordon et al. [1984] and May and Butler [1986]. Bold line represents the synthetic APW path of Gordon et al. [1984], calculated using a paleomagnetic Euler pole (PEP) model. Paleomagnetic poles for the APW path of May and Butler [1986]: RP1, Red Peak Formation of the Chugwater Group [Herrero-Brevera and Helsley, 1983]; RP2, Red Peak Formation of the Chugwater Group [Shive et al., 1984]; M, Moenkopi Formation [Helsley and Steiner, 1974]; MI, Manicouagan Impact Structure [Robertson, 1967; Larochelle and Currie, 1967]; C, Chinle Formation [Reeve and Helsley, 1972]; W, Wingate Sandstone [Reeve, 1975]; K, Kayenta Formation [Steiner and Helsley, 1974]; N1, Newark trend group 1, and N2, Newark trend group 2 [Smith and Noltimier. 1979]: CC, Corral Canyon [May et al.,1986]; G, Glance Conglomerate [Kluth et al., 1982] (see reference and Table 6 for specific ages and locations of synthetic paleomagnetic poles). Projection (for this and all global projections to follow) is orthographic.

east of the evolving Cordilleran arc [Dickinson, 1981]. Source material for these nonmarine, sedimentary rocks came primarily from the Ancestral Rockies and Mogollon Highland located east and south, respectively, of the depositional area [Blakey and Gubitosa, 1983; Clark and Fastovsky, 1986; Poole, 1961]. The adjacent highlands and the evolving Cordillera to the west controlled the trend and morphology of deposition. Modifications of source areas and changes in subsidence rates of basins influenced the lithology and extent of individual formations.

Deposition was interrupted several times by uplift and erosion producing several widespread unconformities [Pipiringos and O'Sullivan, 1978]. The average duration of the unconformities is generally $<2 \mathrm{~m} . y$., and strata are conformable above and below erosion surfaces. The sampling localities for this study are in areas composed of flat-lying, well-exposed Triassic and Jurassic strata that essentially have been undisturbed by deformational or metamorphic events.

Laramide monoclines and extensional structures associated with Basin and Range/Rio Grande extension are principle features of post-Triassic regional deformation. In addition, deformational structures north, northeast, and east of the Colorado Plateau suggest that the plateau may have rotated clockwise by $3^{\circ}$ during the Laramide Orogeny and an additional $2^{\circ}$ during Rio Grande rifting [Hamillon, 1981; Cordell, 1982]. Comparisons of paleomagnetic poles provide further evidence of a small clockwise rotation of the Colorado Plateau since the Late Triassic [Bryan and Gordon, 1990; Steiner, 1988]. We return to this point in the discussion.

\section{SAMPLING AND EXPERIMENTAL PROCEDURES}

The goal of this study was to obtain well-defined Late Triassic and Early Jurassic paleomagnetic poles for the North American craton. This requires sampling well-dated cratonic regions which have a relatively simple deformational history and retain a reliable paleomagnetic record. The Colorado Plateau is a region with little internal deformation from which numerous Mesozoic paleomagnetic poles have been determined [e.g., Steiner and Helsley, 1974; Ekstrand and Buller, 1989]. Although this region possesses possibly the most "straightforward" exposures of early Mesozoic strata in North America, there are complications. The possibility of Colorado Plateau rotation relative to North America may introduce a few degrees of ambiguity in paleomagnetic pole position. In addition, strata at the sampling locations are flat lying and do not allow fold tests. To some degree these complications can be addressed by evaluating constraints on Colorado Plateau rotation and by reversals tests within each lithologic unit. Unfortunately, small-scale features suitable for testing the age of magnetization, such as rip-up clasts, were not found. However, the excellent exposure and structural simplicity of rocks in this region reduce ambiguity that might accompany the magnetization of red beds from more structurally complex and poorly exposed regions.

In previous studies of southwestern red beds [e.g., Reeve and Helsley, 1972; Steiner and Helsley, 1974] only one sample was collected per stratigraphic interval (bed) to maximize stratigraphic coverage with a given number of samples. 
While this method has the advantage of determining the polarity zonation with high fidelity, it may allow specimens with complex magnetizations to be incorporated into determination of paleomagnetic poles. Evaluation of consistency of characteristic remanent magnetization (ChRM) within sedimentary layers is essential. This evaluation is particularly important in the case of red beds where overlapping components from multiple periods of magnetization may produce complex natural remanent magnetization (NRM) [Larson et al., 1982]. Our strategy was to collect multiple cores (610) per sedimentary horizon to evaluate within-layer consistency. Resulting data show that this procedure was effective in identifying complex magnetizations. We have found numerous sedimentary layers within which single specimens appear to retain well-defined ChRM components, yet the directions of these components vary between samples. These complexities result in high within-site dispersion (e.g., $\alpha_{95}>$ $20^{\circ}, k<20$ ) and often streaked distributions of ChRM directions. We attribute some of this behavior to long-term remanent magnetization acquisition by some beds [e.g., Larson et al., 1982]. Although we do not always understand the origin of these complex magnetizations, these poorly defined sitemean directions should not be used for paleomagnetic pole determinations.

In light of the above considerations, collection locations were chosen where continuous stratigraphic sections of layered, fine-grained strata could be sampled. Fine-grained lithologies were preferred because the NRM is generally less complex, possibly because lower permeability prevents prolonged diagenesis. Cores $(2.5 \mathrm{~cm}$ diameter) were drilled in situ and oriented using both a magnetic and, when possible, a Sun compass. Nonmagnetic drill bits and saw blades were employed throughout sample collection and preparation.

Prepared specimens were stored and measured in a magnetically shielded room for the duration of analysis. The NRM of each sample was measured, and a set of pilot specimens from each site was progressively demagnetized. The number and magnitude of demagnetization and measurement steps for additional specimens from each site were based on the results of the pilot studies. All remanence measurements were performed using a 2-axis cryogenic magnetometer. The furnaces used for thermal demagnetization employ thermocouples spaced throughout the sample region so that the temperature of each specimen can be recorded and each specimen can be incrementally demagnetized in steps as small as $3^{\circ} \mathrm{C}$. All demagnetization was conducted in magnetically shielded regions with magnetic inductions less than $5 \mathrm{nT}$.

Components of NRM were evaluated using principal component analysis [Kirschvink, 1980]. The maximum angular deviation (MAD) of the least squares lines were used as a selection criterion. In general, specimen components of characteristic remanent magnetization with $\mathrm{MAD}>15^{\circ}$ were regarded as poorly defined and were rejected from further analysis.

\section{The Upper Shale Member of the Chinle Formation}

\section{Geologic Selting and Age}

The Upper Shale Member of the Chinle Formation was sampled at three locations in east central New Mexico (Figure 2a). Inconsistency of stratigraphic nomenclature and location of these sedimentary rocks in a depositional basin separate from the Chinle Formation of the Colorado Plateau has led Lucas and Hunt [1989] to consider the members of the Chinle Formation of east central New Mexico as separate formations. Lucas and Hunt refer to the Upper Shale Member of the Chinle Formation as the Bull Canyon Formation. However, we use the original name to be consistent with previous usage in the paleomagnetic literature.

The Upper Shale Member includes up to $110 \mathrm{~m}$ of mostly reddish-brown mudstone and sandstone, with minor amounts of siltstone and conglomerate. Minor amounts of a red, finegrained carbonate also are present at the Mesa Redonda location. The lithologies indicate both lacustrine and fluvial depositional settings [Lucas et al., 1985]. Contacts with the underlying Cuervo Member of the Chinle Formation (Trujillo Formation of Lucas and Hunt [1989]) and with the overlying Redonda Member of the Chinle Formation (Redonda Formation of Lucas and Hunt [1989]) are conformable [Lucas et al., 1985].

The Upper Shale Member of the Chinle Formation is the most fossiliferous unit in the Late Triassic section of east central New Mexico [Lucas et al., 1985]. Fossils include vertebrates, invertebrates, and plants of Late Triassic (Norian) age. Phytosaur fauna lacking primitive Carnian characteristics but containing more advanced Norian phytosaur [Lucas et al., 1985] suggest an early Norian age. Evaluation of vertebrates, ostracodes and charophytes indicates that the Upper Shale Member is correlative with the upper portion of the Petrified Forest Member of the Chinle Formation (S. G. Lucas, personal communication, 1989). The Upper Shale Member is distinctly older than the Redonda, Church Rock, Rock Point, and Owl Rock members of the Chinle Formation (S. G. Lucas, personal communication 1989). These age relationships indicate an earliest Norian age for the Upper Shale Member of the Chinle Formation in east central New Mexico (approximately $223 \mathrm{Ma}$ using the time scale of Harland et al. [1990]).

\section{Paleomagnetic Results}

A total of $50 \mathrm{~m}$ of stratigraphic section was covered by collecting samples from 22 different layers (or sites) at three locations (Figure 2a). NRM intensities ranged from $1 \times 10^{-3}$ $109 \times 10^{-3} \mathrm{~A} / \mathrm{m}$. NRM directions generally were either north or south directed with positive inclinations. Thermal demagnetization of pilot specimens from each site (in up to 14 temperature steps) allowed 7-12 optimal temperatures between $200^{\circ} \mathrm{C}$ and $680^{\circ} \mathrm{C}$ to be selected for treatment of remaining specimens. Alternating field (AF) demagnetization proved ineffective on all mudstone and sandstone samples and only removed a low-coercivity component from specimens of the one carbonate site.

Most specimens contained both low and high unblockingtemperature components of NRM (Figure $3 a$ ). The low-temperature component is unblocked between $200^{\circ} \mathrm{C}$ and $500^{\circ} \mathrm{C}$ and generally is directed downward and northerly. We interpret this component as a viscous magnetization, probably of present field origin. The high-temperature ChRM is either north or south directed with shallow inclination and is completely unblocked between $660^{\circ} \mathrm{C}$ and $680^{\circ} \mathrm{C}$ (Figures $3 a$ and $3 b$ ). An exception is the only fine-grained carbonate layer at site US022; ChRM from this site is unblocked by $580^{\circ} \mathrm{C}$ (Figure $3 \mathrm{c}$ ).

The observations that AF demagnetization was not effective in removing NRM components and thermal demagnetization to $680^{\circ} \mathrm{C}$ was required for complete removal of NRM suggest the NRM is carried predominantly by hematite. Reflected light microscopy, scanning electron microscopy, and X-ray diffraction analysis confirm the presence of both specular and authigenic hematite as well as minor amounts of titanomagnetite. Lack of resolution at the submicron level prevents quantification of the remanence carriers. But the abundance of altered mafic grains, hematite overgrowths, and fine-grained reddish matrix and the paucity of grains with high-temperature 
(a)

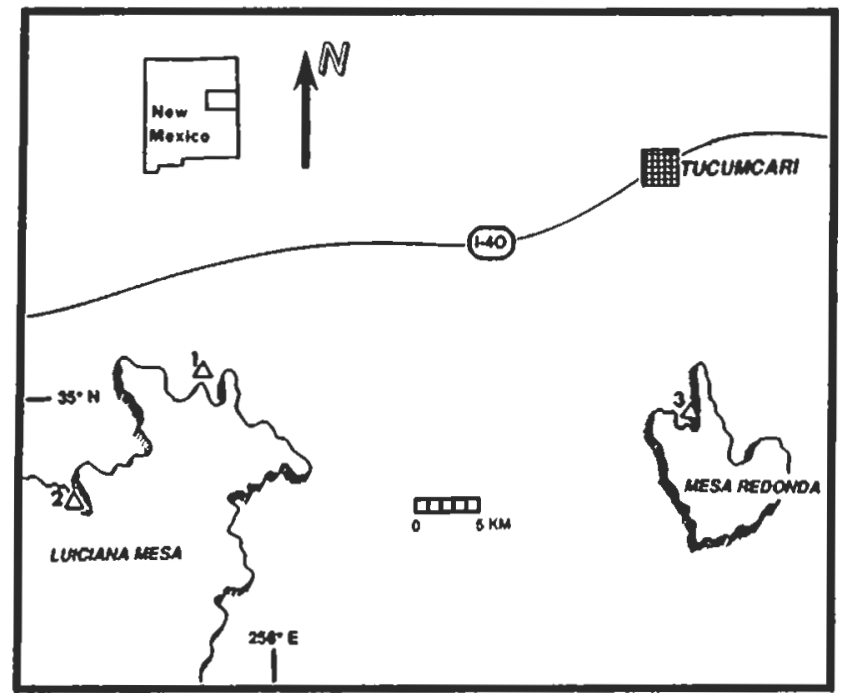

(b)

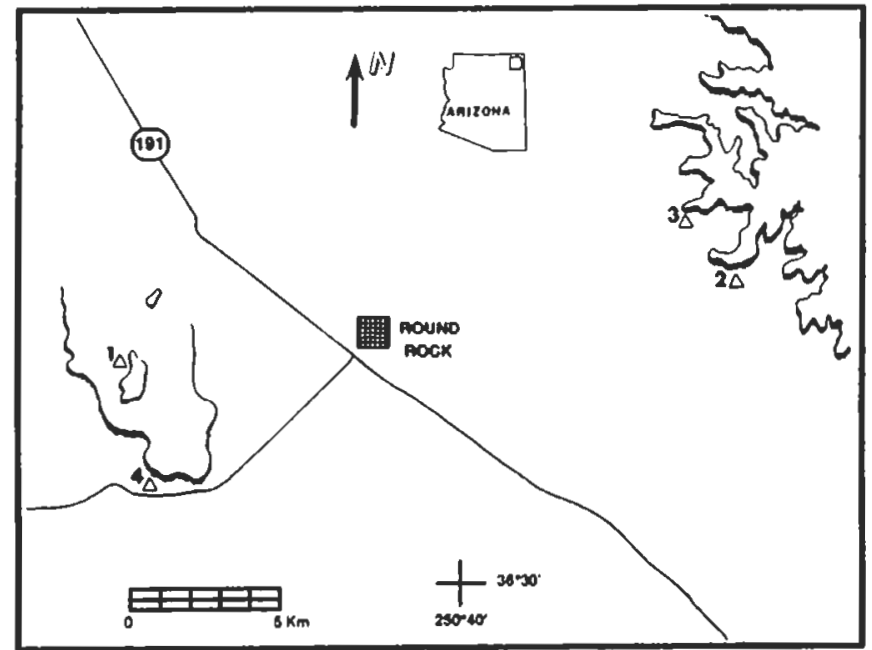

(c)

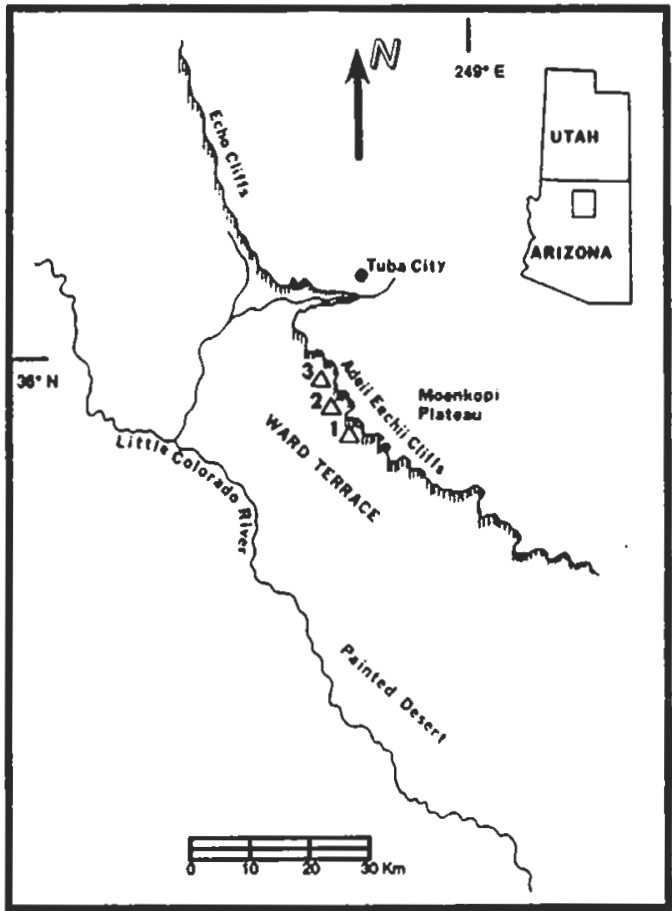

Fig. 2. Index maps of study areas. Specific sampling locations are shown by triangles. (a) Sites of the Upper Shale Member of the Chinle Formation: $1\left(35.02^{\circ} \mathrm{N}, 255.92^{\circ} \mathrm{E}\right)$ US001-005; $2\left(34,97^{\circ} \mathrm{N}, 255.81^{\circ} \mathrm{E}\right)$ US006-014; $3\left(35.00^{\circ} \mathrm{N}\right.$, 256.30 $\mathrm{E}$ ) US015-022. (b) Sites of the Owl Rock Member of the Chinle Formation: $1\left(36.51^{\circ} \mathrm{N}, 250.45^{\circ} \mathrm{E}\right)$ OR001-010; $2\left(36.53^{\circ} \mathrm{N}, 250.68^{\circ} \mathrm{E}\right)$ OR011.029; $3\left(36.57^{\circ} \mathrm{N}, 250.67^{\circ} \mathrm{E}\right)$ OR034-043; $4\left(36.48^{\circ} \mathrm{N}, 250.47^{\circ} \mathrm{E}\right)$ OR044-048. (c) Sites of the Kayenta Formation: $1\left(35.96^{\circ} \mathrm{N}, 248.75^{\circ}\right) \mathrm{KY} 001.017 ; 2\left(35.97^{\circ} \mathrm{N}, 248.74^{\circ} \mathrm{E}\right) \mathrm{KY} 018-029 ; 3\left(35.98^{\circ} \mathrm{N}, 248.73^{\circ} \mathrm{E}\right)$ KY030-035.

exsolution or oxidation features argue for a predominantly chemical origin of the characteristic remanence.

Principal component analysis [Kirschvink, 1980] was used to resolve ChRM components. Least squares line fits using the free and anchored options are indistinguishable. The agreement of ChRM directions derived from these two methods and linear decay of ChRM above $600^{\circ} \mathrm{C}$ to the origin of vector component diagrams indicate isolation of a single, high unblocking-temperature component. For determination of site-mean directions, line fits (using the origin option) were obtained from three to five thermal demagnetization steps on each of four to seven specimens from each site (Table 1).

Six sites (US001, US002, US004, US006, US007, US010) that either failed to yield three or more specimens with MAD $<15^{\circ}$ or contained dispersed ChRM directions $\left(\alpha_{95}>20^{\circ}\right)$ were excluded from further analysis. One site (US019) passed these criteria but yields a site-mean direction greater than two angular standard deviations from the mean of all sites. Inclusion of this site mean in calculation of an Upper Shale pole increases the $95 \%$ confidence region by $0.5^{\circ}$ but does not significantly change the pole position. Because this site is of questionable reliability, we list its direction in Table 1 but omit it from final determination of the paleomagnetic pole (Table 4).

Virtual geomagnetic poles (VGPs) calculated for each of the remaining 15 sites were analyzed using standard Fisher [1953] and modified Bingham [Onstott, 1980] techniques (Tables 1 and 4 and Figure 4). Although intermediate and minimum eigenvector values indicate an elliptical distribution, the pole position derived from the maximum eigenvector is within $0.1^{\circ}$ of the pole calculated using the Fisher analysis (Table 4).

The 15 site-mean VGPs used to calculate the paleomagnetic pole include three northern hemisphere (normal-polarity) VGPs and 12 southern hemisphere (reverse-polarity) VGPs. Five polarity zones are defined within the $50 \mathrm{~m}$ of stratigraphic section of the Upper Shale Member of the Chinle Formation. Additional polarity zones may exist in the unsampled, coarser-grained, or less competent units. A $5.9^{\circ}$ angular distance separates the means of the normal- and (inverted) reverse-polarity VGPs. Although the VGPs pass a 
(a)

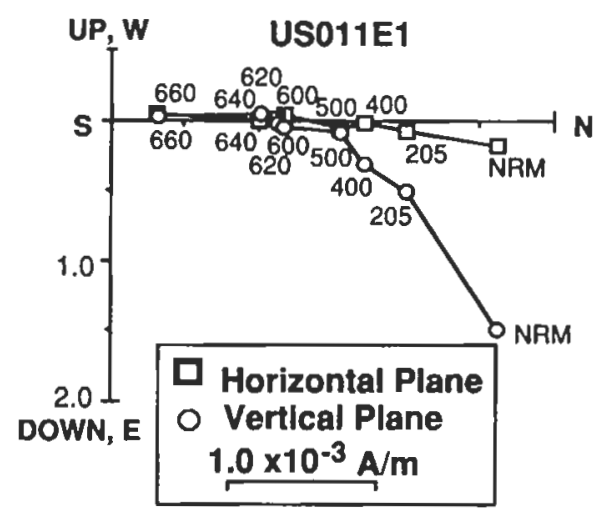

(b)

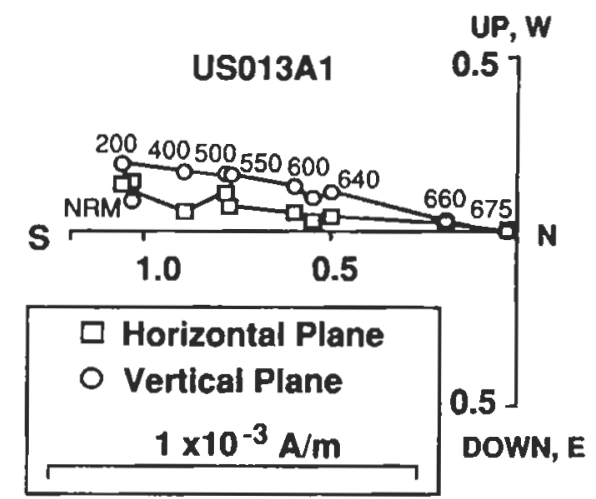

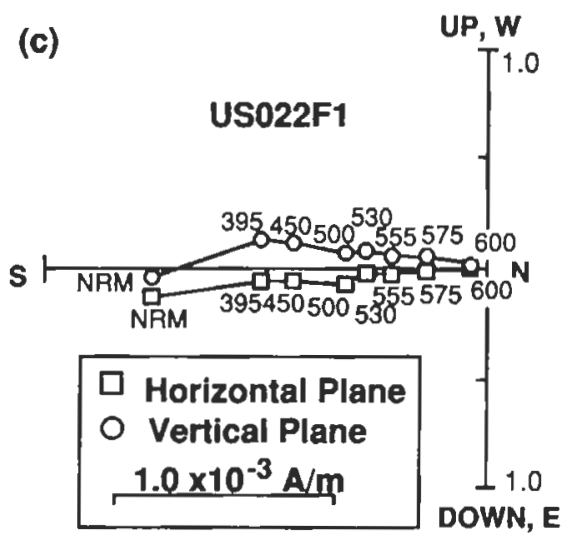

Fig. 3. Vector end point diagrams illustrating demagnetization behavior of typical specimens from the Upper Shale Member of the Chinle Formation. (a) and $(b)$ Representative specimens from fine-grained sandstone sites. (c) Representative specimen from fine-grained carbonate site (US022). Numbers adjacent to data points indicate themal demagnetization temperatures in degrees Celsius.

reversals test [McFadden and Lowes, 1981] at the 5\% significance level, the low number of normal-polarity VGPs (3) prevent a robust test. Furthermore, the McFadden and Lowes test is intended for Fisherian distributions, and a chi-square test [McFadden, 1980] indicates the distribution of site-mean VGPs (Table 4 and Figure 4) is not Fisherian. However, comparing Bingham distributions of the normal- and reversepolarity VGPs indicates substantial overlap of the confidence regions. Unfortunately, a more rigorous reversals test does not exist for comparing non-Fisherian distributions.

We observe no correlation between site-mean VGP position and stratigraphic level, lithology, or sampling location. This suggests that the ellipticity of the VGP distribution is due to either detrital effects (paleocurrents or inclination flattening), sampling of paleosecular variation with suppressed inclination variations, or long-term remanent magnetization acquisition which is not related to stratigraphic position. Petrographic evidence of a chemical origin of the magnetization argues against detrital effects. However, other hypotheses cannot be as easily dismissed. One possibility is that some samples retain both normal- and reverse-polarity Late Triassic magnetizations. A complete overlap of the unblocking-temperature spectra of these components would result in an apparent single component with a direction which lies on a great circle between the two component directions. If a shallow inclination great circle is preferred, then variable degrees of overlap could cause a streak of directions similar to the distribution observed for the Upper Shale Member. This also may explain the streaked VGP distributions reported for Late Triassic and Early Jurassic red beds by Witte and Kent [1989a], Ekstrand and Butler [1989], and Steiner and Helsley [1974]. However, we do not have an explanation for why a shallow inclination great circle path should be preferred; thus the origin of these elliptical VGP distributions is open to question.

\section{OWL ROCK MEMBER OF THE CHINLE FORMATION}

\section{Geologic Setting and Age}

The Owl Rock Member of the Chinle Formation was sampled at four locations in the Round Rock region of northeastern Arizona (Figure $2 b$ ). Stratigraphic sections at these locations include up to $150 \mathrm{~m}$ of red siltstone interstratified with pale red and grey limestone (generally micrite) and minor amounts of sandstone and conglomerate. Contacts with the underlying Petrified Forest and overlying Rock Point members of the Chinle Formation are depositionally continuous 
TABLE 1. Upper Shale Member of the Chinle Formation, Site-Mean Directions and Poles

\begin{tabular}{|c|c|c|c|c|c|c|c|c|c|c|}
\hline Site & $N / N_{0}$ & $\begin{array}{c}\text { Temperature } \\
{ }^{\circ} \mathrm{C}\end{array}$ & $N_{s}$ & $\begin{array}{l}D, \\
\operatorname{deg}\end{array}$ & $\begin{array}{c}I, \\
\text { deg }\end{array}$ & $R$ & $k$ & $\begin{array}{l}\alpha_{95} \\
\text { deg }\end{array}$ & $\begin{array}{l}\text { latP } \\
\text { N }\end{array}$ & ${ }^{\circ} \mathrm{E}$ \\
\hline USOO3 & $5 / 6$ & $600-675$ & 4 & 157.8 & -7.4 & 4.96 & 92 & 8.0 & -52.6 & 294.2 \\
\hline USO05 & $5 / 6$ & $600-675$ & 5 & 166.9 & -1.2 & 4.89 & 36 & 13.0 & -53.5 & 278.3 \\
\hline US008 & $4 / 6$ & $600-640$ & 3 & 359.5 & 19.6 & 3.96 & 77 & 10.5 & 65.1 & 77.0 \\
\hline USO09 & $6 / 6$ & $600-660$ & 4 & 340.6 & 7.00 & 5.89 & 47 & 9.9 & 53.8 & 109.9 \\
\hline USO11 & $6 / 6$ & $600-665$ & 4 & 348.5 & 3.7 & 5.90 & 52 & 9.4 & 55.2 & 96.3 \\
\hline USO12 & $6 / 6$ & $600-670$ & 5 & 183.4 & -10.8 & 5.96 & 141 & 5.7 & .60 .3 & 249.1 \\
\hline US013 & $6 / 6$ & $600-660$ & 4 & 181.1 & -13.2 & 5.99 & 404 & 3.3 & .61 .7 & 253.5 \\
\hline US014 & $5 / 6$ & $600-660$ & 4 & 182.2 & -12.3 & 4.92 & 51 & 10.9 & .61 .2 & 251.4 \\
\hline US015 & $6 / 8$ & $600-665$ & 4 & 161.6 & -5.6 & 5.91 & 56 & 9.0 & .53 .6 & 288.4 \\
\hline US016 & $7 / 8$ & $600-665$ & 4 & 167.3 & 0.4 & 6.90 & 60 & 7.9 & .52 .9 & 277.6 \\
\hline US017 & $6 / 6$ & $600-660$ & 4 & 165.1 & -1.5 & 5.95 & 105 & 6.6 & -53.1 & 281.6 \\
\hline US018 & $6 / 8$ & $600-660$ & 4 & 184.9 & 5.1 & 5.96 & 122 & 6.1 & -52.2 & 248.3 \\
\hline US019* & $7 / 8$ & $600-665$ & 4 & 198.0 & 9.7 & 6.84 & 38 & 9.9 & -46.7 & 229.6 \\
\hline USO20 & $5 / 6$ & $600-665$ & 4 & 184.1 & .1 .2 & 4.94 & 63 & 9.7 & .55 .4 & 249.0 \\
\hline US021 & $5 / 6$ & $600-660$ & 4 & 184.9 & 0.2 & 4.97 & 139 & 6.5 & -54.6 & 247.7 \\
\hline USO22 & $6 / 6$ & $500-575$ & 4 & 177.6 & -8.7 & 5.98 & 310 & 3.8 & -59.3 & 261.0 \\
\hline
\end{tabular}

$N$, number of specimens used to desermine site-mean direction, virtual geomagnetic pole (VGP), and associated statistics; $N_{o}$, number of specimens thermally demagnetized; Temperature, maximum themal demagnetization temperature range over which principal component analysis was applied; $N_{s}$ number of demagnetization steps within demagnetization temperature range; $D$, site-mean declination; $l$, site-mean inclination; $R$, length of resultant of $N$ unit vectors; $k$, estimate of Fisher precision parameter; $\alpha_{95 .}$ radius of the cone of $95 \%$ confidence about the mean direction: latP, latitude of site-mean pole (virtual geomagnetic pole: VGP); lonP, longitude of site-mean pole (VGP).

* Site excluded from paleomagnetic pole determination.

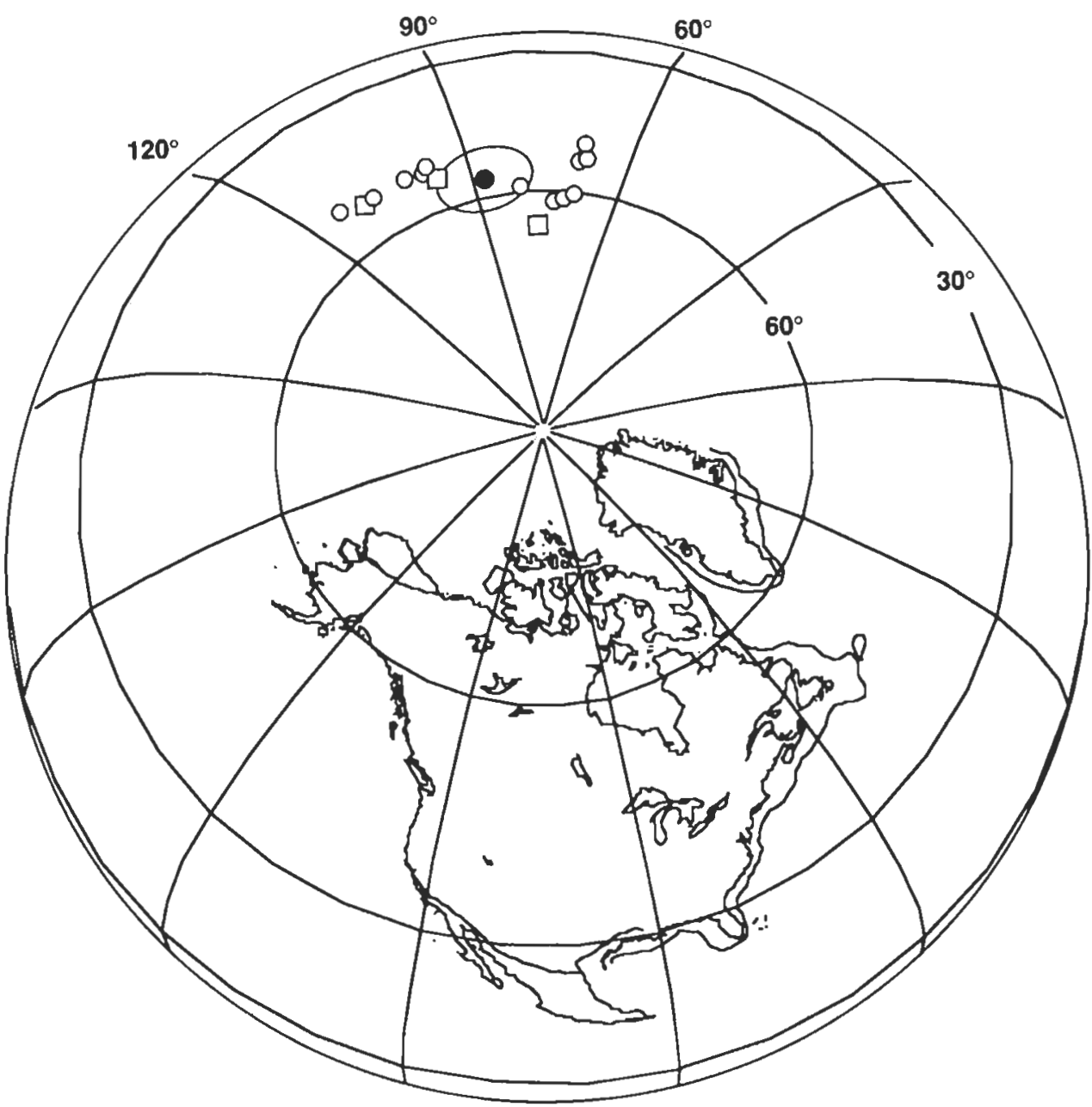

Fig. 4. Site-mean virtual geomagnetic poles (VGPs) and paleomagnetic pole from the Upper Shale Member of the Chinle Formation. Open squares are northem hemisphere VGPs. Open circles are southern hemisphere VGPs inverted to plot in the northem hemisphere. The solid circle is the paleomagnetic pole surrounded by its $95 \%$ confidence limit. 
[Stewart et al., 1972]. The fine texture, even bedding, and fossil types indicate that the Owl Rock Member was deposited primarily in freshwater lakes [Blakey and Gubitosa, 1983; Stewart et al., 1972]. Much of the limestone appears to have resulted from replacement of volcanic ash within this laucustrine environment [Blakey and Gubitosa, 1983].

Fossil vertebrate fauna including primitive archosaurs (e.g., phytosaurs) indicate a late Triassic age for the upper portion of the Chinle [Long and Padian, 1986; Padian, 1986a, b]. Although fossil pollen has not been found in the Owl Rock Member, palynological data and vertebrate faunal evidence suggest that the Carnian-Norian stage boundary occurs at about the Sonsela Sandstone Bed of the underlying Petrified Forest Member [Litwin, 1986; S. G. Lucas, written communication, 1990]. In addition, fossil pollen in the overlying
Church Rock Member is no younger than middle Norian [Litwin, 1986]. This brackets the age of the Owl Rock Member as early to middle Norian (approximately 218-213 $\mathrm{Ma}$.

Paleomagnetic Results

Samples from 43 sites covering $90 \mathrm{~m}$ of section were collected at four locations (Figure $2 b$ ). Fourteen sites are from micrite layers and the remaining were from siltstone or finegrained sandstone. Seven additional sites were collected from the overlying Rock Point Member but did not yield reliable ChRM directions. NRM intensities of the Owl Rock specimens range from $1 \times 10^{-4}$ to $5 \times 10^{-3} \mathrm{~A} / \mathrm{m}$. The NRM directions were either north or south directed, generally with (a)

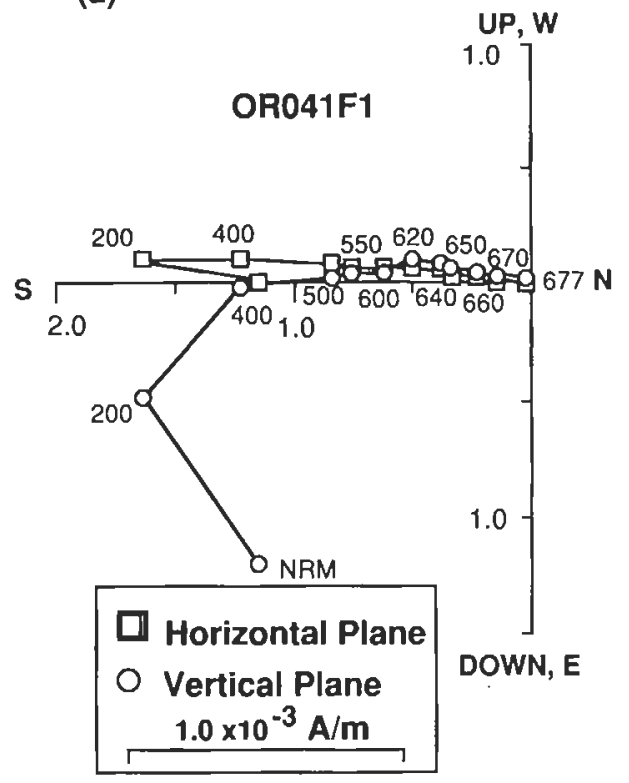

(b)

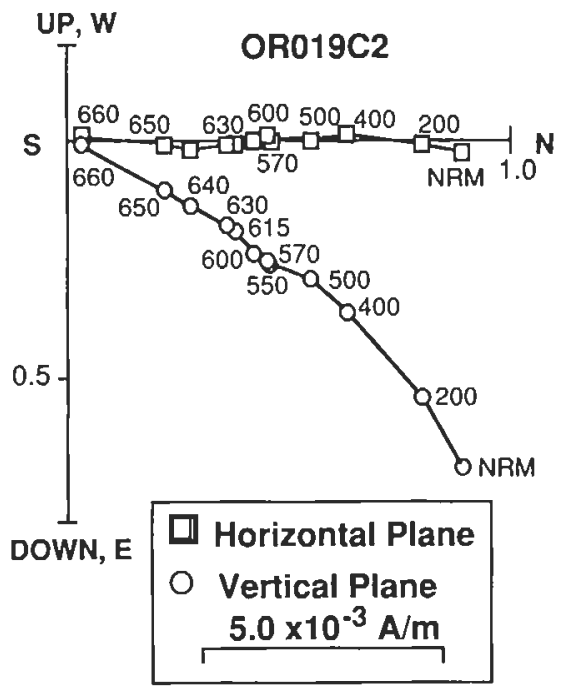

(c)

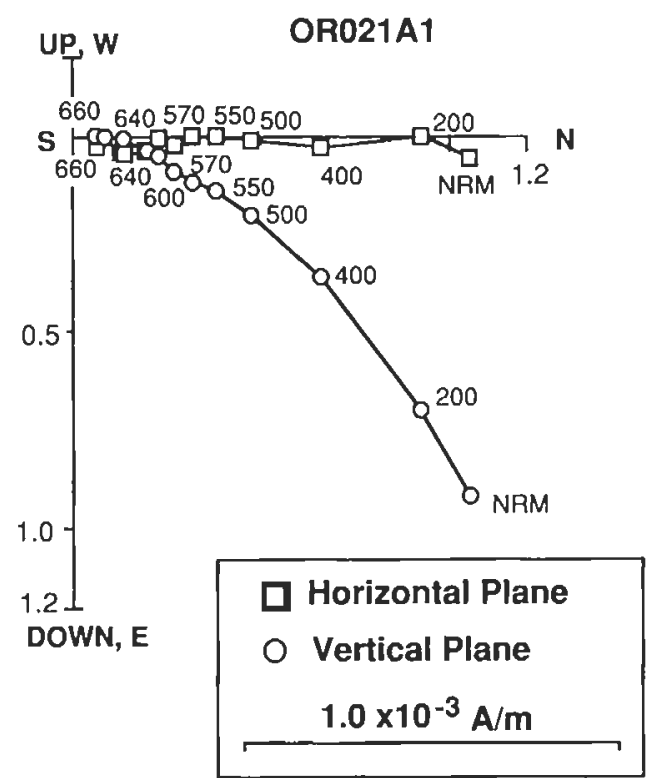

Fig. 5. Vector end point diagrams illustrating demagnetization behavior of typical specimens from the Owl Rock Member of the Chinle Formation. (a) Representative of specimens from siltstone sites. (b) Representative of specimens from micrite sites. (c) A rare example where both the steeper "micrite component" and lower inclination "high-temperature component" is contained in a single micrite specimen. Numbers adjacent to data points indicate themal demagnetization temperatures in degrees Celsius. 
positive inclinations. Petrographic studies of sandstone specimens reveal evidence for both detrital magnetite and hematite grains as well as authigenic and altered mafic grains. The small grain size of the micrite samples prevented examination of their magnetic mineralogy. For the coarser-grained specimens, however, the abundance of authigenic minerals and minor amounts of detrital magnetic grains favor a chemical origin of the ChRM.

For 38 sites, thermal demagnetization allowed isolation of one to three components of NRM. Most specimens contained a steeply inclined, low unblocking-temperature component removed by $400^{\circ} \mathrm{C}-500^{\circ} \mathrm{C}$ (Figure $5 \mathrm{a}$ ). Its direction is generally indistinguishable from that of the present geomagnetic field and is interpreted as a viscous magnetization.

Twenty-six sites contain specimens with a shallow inclination, high unblocking-temperature ChRM (Figure 5a). However, eight of these sites were rejected using the criteria of $\mathrm{MAD}<15^{\circ}$ and intrasite consistency of ChRM directions. For the remaining 18 sites, linear decay of the ChRM components to the origin of vector component diagrams and indistinguishable results using free and anchored line fits indicate isolation of a single component of magnetization. The direction of this component was calculated for each specimen by fitting a line to three or more data points (using the origin option) observed following demagnetization steps between $600^{\circ} \mathrm{C}$ and $680^{\circ} \mathrm{C}$. These line-fit directions were used to calculate Fisher [1953] site-mean directions, VGPs, and associated statistics (Table 2).
Three of the 14 micrite sites (OR048, 025, 009) retain only a shallow-inclination, high unblocking-temperature ChRM and are included in the 18 sites described above. These sites were sampled at a location different (locations 1 and 4 in Figure $2 b$ ) from the other micrite sites, suggesting that these samples were not affected by the event that resulted in the "micrite component" discussed below.

Of the 18 sites containing this highest unblocking-temperature ChRM component, five are normal polarity and 13 are reverse polarity (Figure $6 a$ and Tables 2 and 4). These sites define five polarity zones within the $90 \mathrm{~m}$ of stratigraphic section sampled. Additional polarity zones may exist within unsampled strata. A reversals test [McFadden and Lowes, $1981]$ is passed at the $5 \%$ significance level and indicates a $5.6^{\circ}$ angular distance between means of normal- and (inverted) reverse-polarity VGPs. These observations suggest successful removal of secondary components and isolation of a magnetization acquired soon after deposition.

Comparison of the dispersion of site-mean VGPs with that observed in the global compilation of paleosecular variation for the last 5 m.y. [McFadden and McElhinny, 1984] indicates that the VGP dispersion from the OwI Rock Member is less dispersed at $5 \%$ significance level. Rather than indicating insufficient averaging of geomagnetic secular variation, we attribute the low VGP dispersion to intrasite (and even intrasample) temporal averaging of secular variation during acquisition of the chemical remanent magnetization.

The Owl Rock Member paleomagnetic pole (HT in Figure 6)

TABLE 2. Owl Rock Member of the Chinle Formation, Site-Mean Directions and Poles

\begin{tabular}{|c|c|c|c|c|c|c|c|c|c|c|}
\hline Site & $N / N_{o}$ & $\begin{array}{c}\text { Temperatur } \\
{ }^{\circ} \mathrm{C}\end{array}$ & $N_{s}$ & $\begin{array}{c}D \\
\text { deg }\end{array}$ & $\begin{array}{c}I, \\
\operatorname{deg}\end{array}$ & $R$ & $k$ & $\begin{array}{l}\alpha_{95} \\
\text { deg }\end{array}$ & $\begin{array}{l}\text { latP } \\
{ }^{\circ} \mathrm{N}\end{array}$ & $\begin{array}{l}\operatorname{lon} P \\
{ }^{\circ} \mathrm{E}\end{array}$ \\
\hline
\end{tabular}

Highest-Temperature Component

\begin{tabular}{lrrrrrrrrrr} 
OR001 & $6 / 6$ & $620-670$ & 4 & 182.4 & -3.9 & 5.90 & 50 & 9.6 & -55.4 & 246.3 \\
OR002 & $5 / 6$ & $620-670$ & 4 & 180.8 & 2.1 & 4.95 & 85 & 8.4 & -52.4 & 249.1 \\
OR009 & $5 / 6$ & $600-670$ & 5 & 3.8 & 5.9 & 4.82 & 23 & 16.5 & 56.3 & 63.7 \\
OR010 & $6 / 6$ & $620-660$ & 4 & 187.7 & -3.5 & 5.94 & 84 & 7.4 & -54.5 & 237.1 \\
OR012 & $3 / 7$ & $600-670$ & 5 & 178.8 & -10.7 & 2.95 & 44 & 18.0 & -58.9 & 253.1 \\
OR014 & $5 / 6$ & $620-670$ & 4 & 186.5 & -10.5 & 4.92 & 50 & 10.9 & -58.2 & 238.3 \\
OR025 & $6 / 6$ & $620-660$ & 4 & 176.6 & -12.8 & 5.96 & 132 & 5.9 & -59.8 & 257.4 \\
OR026 & $6 / 6$ & $620-660$ & 4 & 10.1 & 12.8 & 5.91 & 55 & 9.1 & 58.6 & 51.1 \\
OR028 & $6 / 6$ & $620-670$ & 4 & 179.5 & -11.5 & 5.93 & 73 & 7.9 & -59.3 & 251.7 \\
OR029 & $3 / 8$ & $600-670$ & 5 & 183.4 & 5.0 & 2.98 & 101 & 12.3 & -50.8 & 245.4 \\
OR034 & $5 / 8$ & $600-675$ & 5 & 6.9 & 11.1 & 4.82 & 23 & 16.5 & 58.4 & 57.4 \\
OR035 & $4 / 8$ & $620-670$ & 4 & 175.9 & -4.9 & 3.93 & 44 & 14.1 & -55.7 & 258.0 \\
OR038 & $3 / 8$ & $600-670$ & 5 & 184.0 & -2.9 & 2.97 & 66 & 15.3 & -54.7 & 243.8 \\
OR041 & $6 / 7$ & $600-670$ & 5 & 180.8 & -3.2 & 5.94 & 86 & 7.3 & -55.0 & 249.2 \\
OR044 & $6 / 8$ & $600-670$ & 5 & 355.1 & 15.7 & 5.90 & 50 & 9.5 & 61.2 & 80.7 \\
OR046 & $4 / 7$ & $620-670$ & 4 & 174.6 & 6.0 & 3.92 & 39 & 15.0 & -50.2 & 259.0 \\
OR047 & $4 / 8$ & $600-670$ & 5 & 12.3 & 8.1 & 3.98 & 147 & 7.6 & 55.7 & 48.4 \\
OR048 & $3 / 8$ & $600-670$ & 5 & 181.5 & -8.3 & 2.99 & 199 & 8.8 & -57.7 & 247.7 \\
& & & & & & & & & & \\
& & & & Micrite & Component & & & & \\
OR011 & $3 / 5$ & $600-640$ & 3 & 353.0 & 39.1 & 2.98 & 97 & 12.6 & 74.4 & 95.2 \\
OR016 & $5 / 5$ & $600-640$ & 3 & 0.8 & 28.3 & 4.95 & 85 & 8.4 & 68.5 & 68.7 \\
OR018 & $5 / 8$ & $575-640$ & 4 & 358.8 & 26.6 & 4.98 & 230 & 5.1 & 67.5 & 73.8 \\
OR019 & $4 / 5$ & $575-640$ & 4 & 359.2 & 25.9 & 4.00 & 891 & 3.1 & 67.1 & 72.7 \\
OR021 & $5 / 5$ & $575-640$ & 4 & 1.5 & 21.3 & 4.93 & 56 & 10.4 & 64.5 & 67.2 \\
OR022 & $4 / 5$ & $570-640$ & 4 & 359.1 & 27.9 & 3.96 & 85 & 10.0 & 68.3 & 72.9 \\
OR023 & $4 / 5$ & $600-650$ & 4 & 5.4 & 33.9 & 3.97 & 115 & 8.6 & 71.4 & 54.4 \\
OR027 & $4 / 6$ & $590-650$ & 4 & 353.9 & 25.7 & 3.92 & 37 & 15.3 & 66.4 & 85.6 \\
OR040 & $4 / 8$ & $565-640$ & 4 & 2.8 & 26.5 & 3.99 & 446 & 4.4 & 67.3 & 63.7 \\
& & & & & & & & & & \\
\hline
\end{tabular}




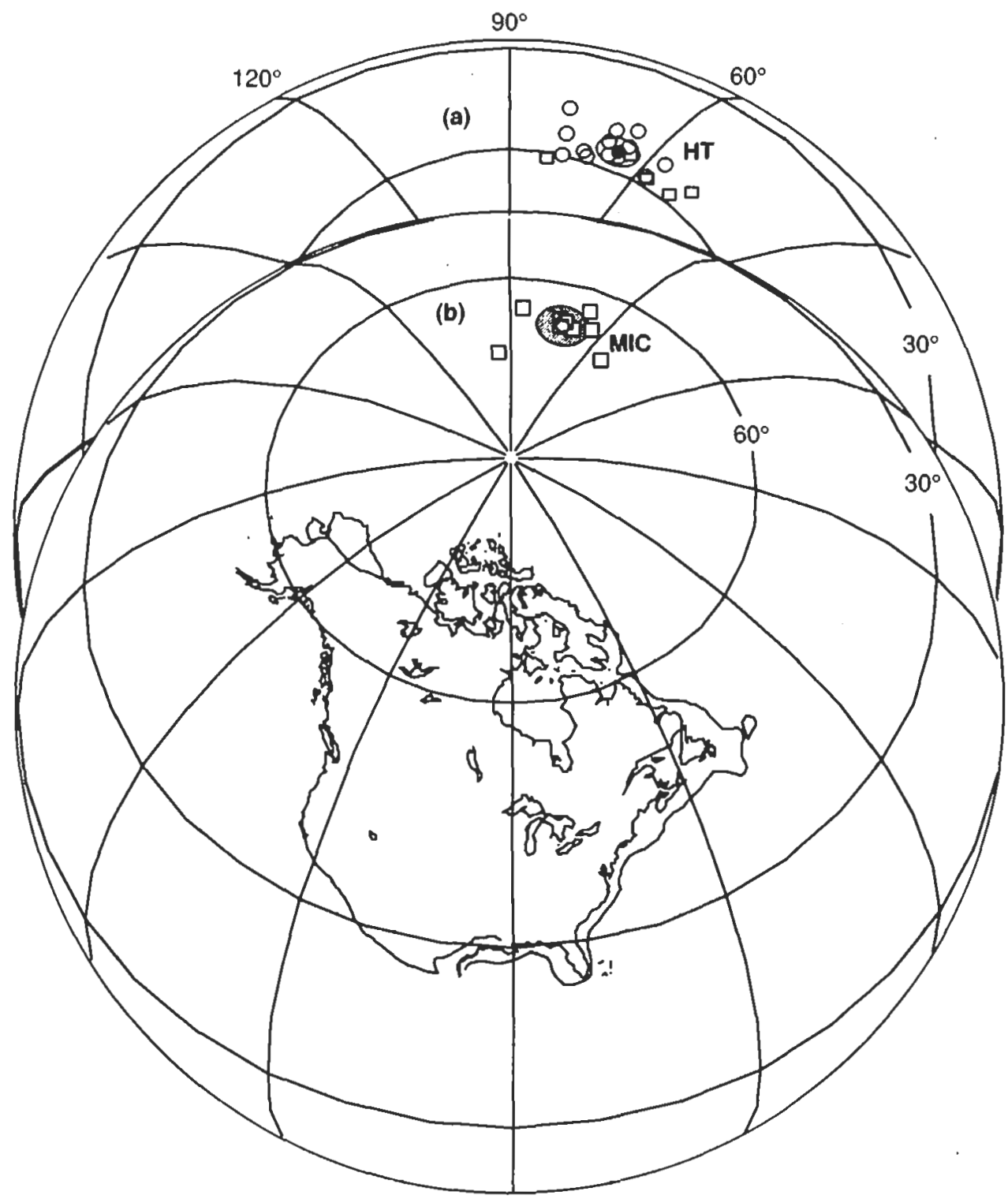

Fig. 6. Site-mean virtual geomagnetic poles (VGPs) and paleomagnetic poles from the Owl Rock Member of the Chinle Formation. (a) Site-mean VGPs calculated from the "highest-temperature" (HT) component. Open squares are northem hemisphere VGPs, and open circles are inverted southem hemisphere VGPs. Solid circle and open oval are the resulting paleomagnetic pole and confidence limit. (b) Site-mean VGPs calculated from the "micrite" (MIC) component. Symbol conventions are the same as Figure $6 a$.

calculated using the method of Fisher [1953] is indistinguishable from a pole calculated using a modified Bingham [Onstolt, 1980] method (Table 4). In addition, the Bingham method yields intermediate and minimum eigenvector values consistent with a Fisherian VGP distribution.

Of the micrite sites, nine exhibit a component of NRM which is unblocked between $400^{\circ} \mathrm{C}$ and $660^{\circ} \mathrm{C}$ (Figures $5 b$ and $5 c$ and Table 2). These sites are from a $50-\mathrm{m}$ stratigraphic section in one region (locations 2 and 3 in Figure $2 b$ ), and all retain a component (the "micrite component") which has a northerly declination and a distinctly steeper inclination than the ChRM observed for the micrite lithologies at the Round Rock location (Figure $2 b$ ). The micrite component is always normal polarity, and it sometimes occurs as a distinct intermediate unblocking-temperature component $\left(400^{\circ}-640^{\circ} \mathrm{C}\right.$, Figure $5 c$ ). Furthermore, the site-mean VGPs calculated from this component fall on a great circle connecting the present geographic pole and Late Triassic poles (Figure 6). These properties lead us to conclude that the micrite component is the result of overlapping unblocking-temperature spectra of Late Triassic and present geomagnetic field components. However, we can not reject the possibility of a Jurassic remagnetization. In either case, this ambiguity requires excluding these nine micrite sites from determination of the Late Triassic paleomagnetic pole from the Owl Rock Member of the Chinle Formation.

\section{THE KAYENTA FORMATION}

\section{Geologic Setting and Age}

The Kayenta Formation was sampled at three locations in the Ward Terrace region of north-central Arizona (Figure 2c). In this region the Kayenta Formation consists of over $200 \mathrm{~m}$ of hematite cemented mudstone, siltstone, and fine-grained sandstone. Sedimentology indicates both an uplifted conti- 
nental block and volcanic source region to the east and southeast [Clark and Fastovsky, 1986; Poole, 1961]. Texture and stratigraphy suggest deposition in a flood plain environment drained by low-energy, sediment-rich streams [Clark and Fastovsky, 1986]. Deposition was apparently continuous as both the underlying Moenave Formation and overlying Navajo Sandstone intertongue with the Kayenta Formation.

Padian [1989] has identified dermal scutes from the Kayenta Formation belonging to an ornithischian dinosaur (scelidosaurs) that can be correlated to Liassic deposits of southwestern England. Palynomorphic studies summarized by Litwin [1986] indicate a late(?) Hettangian to early Pliensbachian age for the Moenave Formation. While the Kayenta Formation intertongues with the uppermost Moenave Formation, most of its fauna is distinct from the Moenave [Clark and Fastovsky, 1986]. These relationships argue for a Pliensbachian age of the Kayenta Formation (approximately 195-187 Ma).

\section{Paleomagnetic Results}

Approximately $100 \mathrm{~m}$ of stratigraphic section was sampled from 35 sites at three locations (Figure 2c). NRM directions of specimens are typically directed north or south with positive inclinations. NRM intensities range from $1 \times 10^{-3}$ to 1 $\times 10^{-2} \mathrm{~A} / \mathrm{m}$. Petrographic examination reveals the presence

(a)

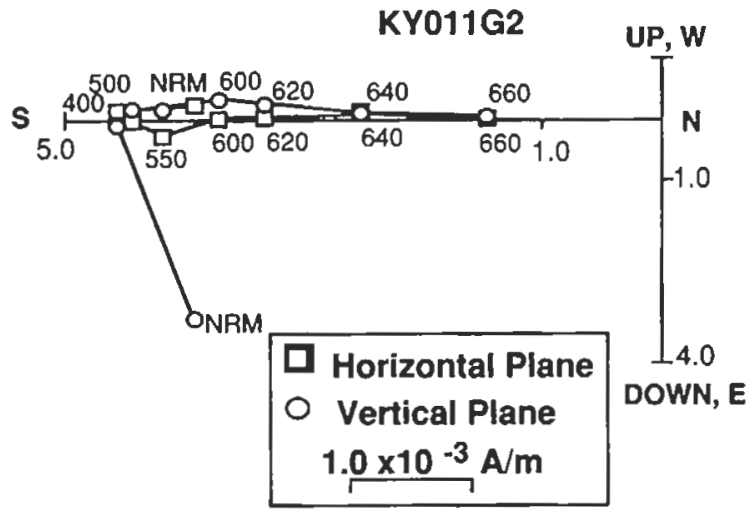

of both authigenic and detrital magnetic minerals. Authigenic minerals include hematite pigment (not resolvable in either reflected light or SEM analysis), optically continuous overgrowths of hematite, and hematite (or goethite) rinds covering iron silicates and iron oxides. Evidence of primary (detrital) magnetic minerals includes grains exhibiting high-temperature oxidation and exsolution features (ilmenite laths, Ti-rich "tiger-striped" regions). Although these observations indicate potential for both detrital and chemical remanent magnetizations, the paucity of detrital features favors a magnetization acquired predominantly by chemically precipitated hematite.

Progressive thermal demagnetization indicated that most specimens contained two components of magnetization. A north directed and steeply inclined component was unblocked by about $550^{\circ} \mathrm{C}$ (Figure 7a). This component was often sharply distinguished from (Figure 7a) but sometimes overlapped with (Figure $7 b$ ), a north or south directed, shallow inclination, high-temperature ChRM that is unblocked above $670^{\circ} \mathrm{C}$ (Figure 7). The direction of the low-temperature component is variable but generally falls on a great circle connecting the present field direction and the high-temperature direction, and it is interpreted as a viscous magnetization.

Linear trends of vector end points to the origin of vector component diagrams indicate isolation of a single high unblocking-temperature $\mathrm{ChRM}$ for demagnetization steps (b)

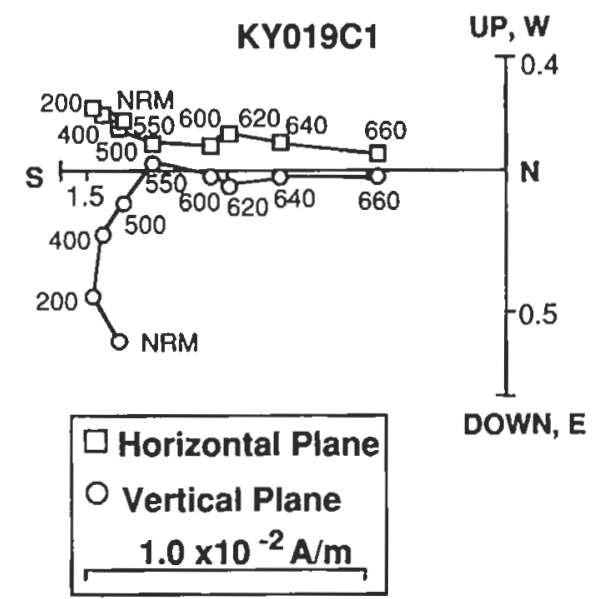

(c)

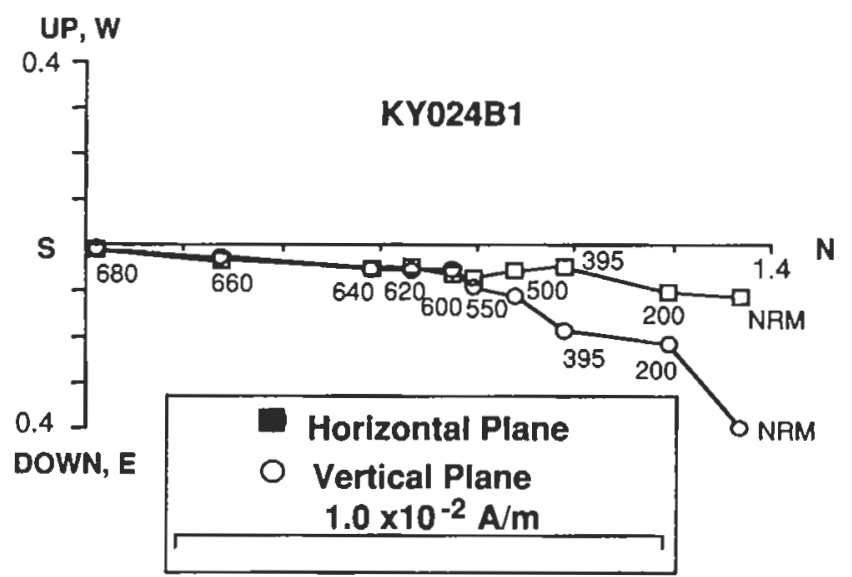

Fig. 7. Vector end point diagrams illustrating demagnetization behavior of typical specimens from the Kayenta Formation. Numbers adjacent to data points indicate thermal demagnetization temperatures in degrees Celsius. 
above $620^{\circ} \mathrm{C}$. This is confirmed by agreement of least squares line fits to these demagnetization steps using the anchored and free options. The ChRM directions used in the final analysis were obtained by fitting least squares lines to three or more demagnetization steps between $600^{\circ} \mathrm{C}$ and $670^{\circ} \mathrm{C}$ using the origin option. A standard Fisher [1953] analysis of these directions was used to calculate site-mean ChRM directions, virtual geomagnetic poles (VGPs), and associated statistics (Table 3 ).

Twelve sites were excluded from the paleomagnetic pole determination. Eleven sites did not allow resolution (MAD > $15^{\circ}$ ) of the high-temperature component. The twelfth site was rejected because its direction was well over two angular standard deviations $\left(15.4^{\circ}\right)$ from the mean of all 24 site-mean directions.

The site-mean directions from the remaining 23 sites define four polarity zones, although additional zones may exist in unsampled regions. Fourteen sites have normal polarity and nine have reverse polarity (Figure 8 and Table 4). The means of the normal- and (inverted) reverse-polarity VGPs are separated by $4.5^{\circ}$ and are statistically indistinguishable using the method of McFadden and Lowes [1981] at the 5\% significance level. This positive reversals test suggests the magnetization was acquired soon after deposition and argues for successful removal of secondary components.

Comparison of the dispersion of the site-mean VGPs with that observed in the global compilation of paleosecular variation for the last 5 m.y. [McFadden and McElhinny, 1984] indicates that the VGP dispersion from the Kayenta Formation is less dispersed at 5\% significance level. We attribute this low VGP dispersion to temporal averaging of secular variation during acquisition of the chemical remanent magnetization. Therefore a paleomagnetic pole calculated from the VGPs (Table 4 ) represents the axial geocentric dipole field during the time of acquisition. Although this new pole has a smaller confidence region, it is statistically indistinguishable from the paleomagnetic pole obtained from the Kayenta Formation in Utah by Steiner and Helsley [1974].

\section{Rotation of the Colorado Plateau}

The paleomagnetic poles from the Owl Rock Member of the Chinle Formation, the Moenave Formation, and the Kayenta Formation are from a regional stratigraphic succession on the Colorado Plateau. The relative ages are securely known, and the poles clearly define a cusp in the APW path as viewed from the Colorado Plateau. Possible rotations of the Colorado Plateau with respect to North America east of the Rio Grande Rift raise questions about how poles from the Colorado Plateau may be compared with poles from other regions of North America. The following analysis of Colorado Plateau rotation evaluates the magnitude and timing of plateau rotation and leads to a realistic correction for Colorado Plateau rotation.

The concept of the Colorado Plateau moving as a rigidblock has been suggested by several authors [e.g., Hamilton and Myers, 1966; Sales, 1968] to explain the contrast in deformational styles between the Colorado Plateau and surrounding areas. Only recently have attempts been made to specify the amount, sense, and timing of movement. Three approaches have been used to determine possible rigid-block motion of the Colorado Plateau. Hamilion [1981] calculated motion based on Laramide and Rio Grande Rift structures which he attributed to at least two periods of clockwise motion of the Colorado Plateau. Steiner [1986, 1988] determined plateau rotation by comparing Middle to Late Devonian, late Pennsylvanian, Early Permian, and Triassic paleomagnetic poles from the Colorado Plateau with poles of the same ages from elsewhere in North America. Bryan and Gordon [1986, 1990] applied a PEP model for APW and calculated the Colorado Plateau rotation required to minimize dispersion between paleomagnetic poles from the Colorado

TABLE 3. Kayenta Formation, Site-Mean Directions and Paleomagnetic Poles

\begin{tabular}{|c|c|c|c|c|c|c|c|c|c|c|}
\hline Site & $N / N_{O}$ & $\begin{array}{c}\text { Temperature } \\
{ }^{\circ} \mathrm{C}\end{array}$ & $N_{s}$ & $\begin{array}{l}D \\
\text { deg }\end{array}$ & $\begin{array}{c}I, \\
\operatorname{deg}\end{array}$ & $R$ & $k$ & $\begin{array}{l}\alpha_{95} \\
\text { deg }\end{array}$ & $\begin{array}{l}{ }^{\circ} \mathrm{N} P \\
\mathrm{~N}\end{array}$ & $\begin{array}{l}\operatorname{lon} P \\
{ }^{\circ} E\end{array}$ \\
\hline KY002 & $5 / 6$ & $620-675$ & 4 & 180.5 & 2.3 & 4.97 & 139 & 6.5 & -52.9 & 248.0 \\
\hline KYO06 & $4 / 6$ & $600-665$ & 4 & 172.2 & -11.3 & 3.97 & 119 & 8.5 & -58.9 & 263.9 \\
\hline KY007 & $4 / 6$ & $600-670$ & 5 & 182.3 & -5.7 & 3.93 & 43 & 14.1 & -56.8 & 244.6 \\
\hline KY009 & $6 / 6$ & $600-675$ & 5 & 0.5 & 15.0 & 5.94 & 80 & 7.5 & 61.7 & 67.7 \\
\hline KYO10 & $5 / 6$ & $600-660$ & 4 & 6.3 & 8.4 & 4.94 & 69 & 9.3 & 57.7 & 56.9 \\
\hline KY011 & $6 / 6$ & $600-660$ & 4 & 180.7 & -2.0 & 5.84 & 32 & 12.1 & -55.0 & 247.6 \\
\hline KYO12 & $6 / 6$ & $600-660$ & 4 & 351.2 & 10.8 & 5.98 & 311 & 3.8 & 58.4 & 85.7 \\
\hline KY013 & $6 / 6$ & $600-675$ & 5 & 9.3 & 10.6 & 5.99 & 538 & 2.9 & 58.2 & 51.0 \\
\hline KY014 & $6 / 6$ & $600-660$ & 4 & 8.2 & 14.5 & 5.97 & 171 & 5.1 & 60.5 & 52.1 \\
\hline KY015 & $6 / 6$ & $600-675$ & 5 & 3.8 & 14.0 & 5.99 & 922 & 2.2 & 61.0 & 61.0 \\
\hline KY016 & $4 / 6$ & $600-665$ & 4 & 180.4 & -17.2 & 3.97 & 96 & 9.4 & -62.9 & 247.8 \\
\hline KY017 & $6 / 6$ & $600-665$ & 4 & 181.7 & -16.0 & 5.98 & 253 & 4.2 & -62.2 & 245.2 \\
\hline KY018 & $6 / 6$ & $600-675$ & 5 & 183.3 & -11.8 & 5.93 & 74 & 7.8 & -59.8 & 242.2 \\
\hline KY019 & $5 / 6$ & $600-675$ & 5 & 178.5 & 9.6 & 4.95 & 84 & 8.4 & -49.2 & 251.1 \\
\hline KY020 & $6 / 6$ & $600-665$ & 4 & 172.6 & -0.0 & 5.99 & 407 & 3.3 & -53.4 & 261.2 \\
\hline KY022 & $6 / 6$ & $600-675$ & 5 & 358.5 & 11.1 & 5.91 & 57 & 9.0 & 59.6 & 71.8 \\
\hline KY023 & $6 / 6$ & $600-660$ & 4 & 358.6 & 8.7 & 5.97 & 159 & 5.3 & 58.4 & 71.4 \\
\hline KY024 & $5 / 6$ & $600-675$ & 5 & 7.7 & 9.3 & 4.98 & 186 & 5.6 & 57.9 & 54.3 \\
\hline KY025 & $5 / 6$ & $600-665$ & 4 & 0.2 & 23.7 & 4.89 & 38 & 12.6 & 66.4 & 68.2 \\
\hline KY026 & $6 / 6$ & $600-660$ & 4 & 358.5 & 9.8 & 5.92 & 65 & 8.4 & 59.0 & 71.6 \\
\hline KY030 & $6 / 6$ & $600-665$ & 4 & 13.3 & 10.2 & 5.97 & 153 & 5.4 & 56.8 & 44.0 \\
\hline KY031 & $6 / 6$ & $600-665$ & 4 & 357.5 & 11.9 & 5.99 & 361 & 3.5 & 60.0 & 73.8 \\
\hline KY033 & $6 / 6$ & $600-665$ & 4 & 359.8 & 16.0 & 5.90 & 53 & 9.3 & 62.2 & 69.1 \\
\hline
\end{tabular}

Refer to Table 1 for explanations of headings. 


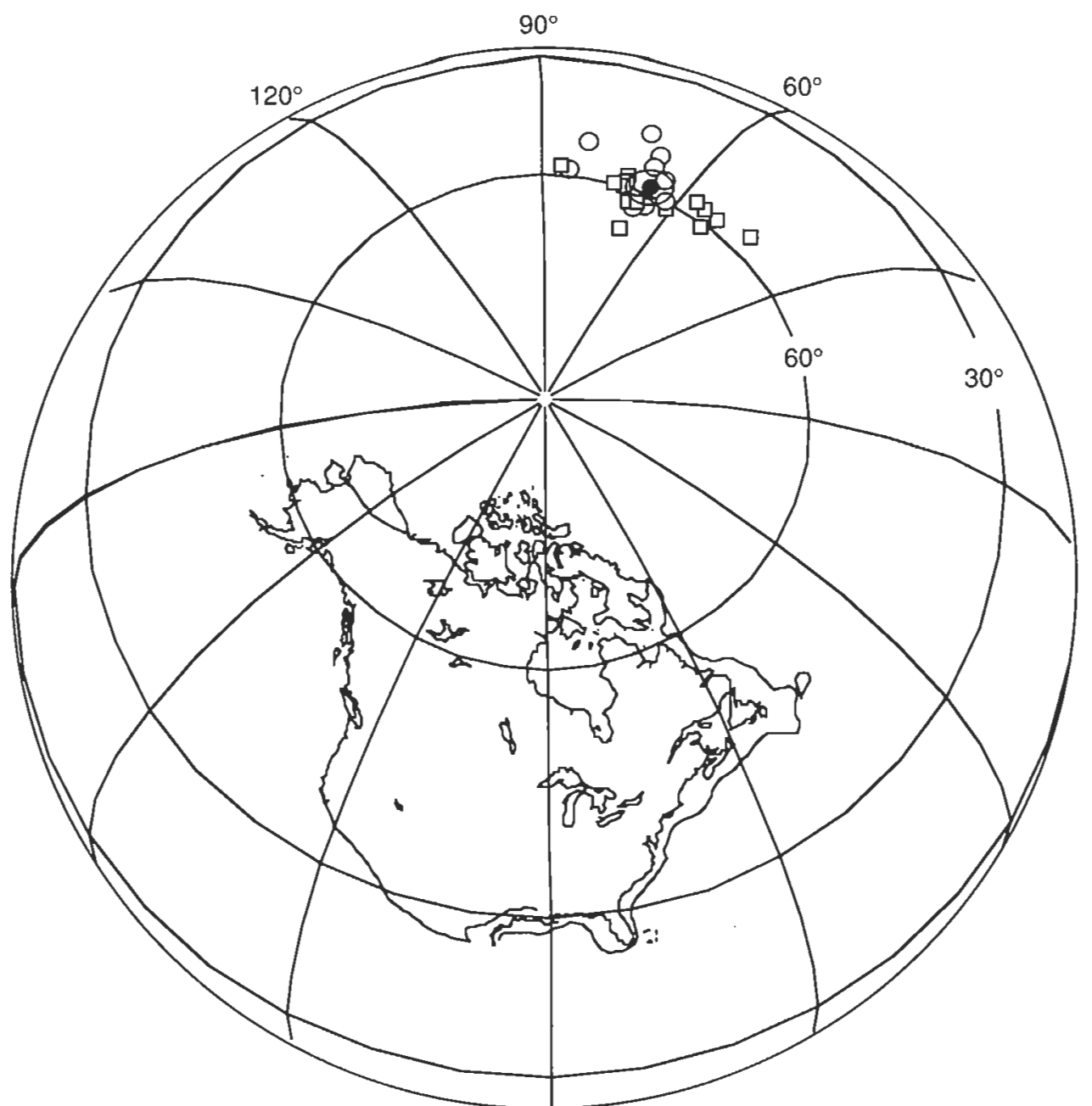

Fig. 8. Site-mean virtual geomagnetic poles (VGPs) and resulting paleomagnetic pole from the Kayenta Formation. Open squares are northem hemisphere VGPs, and open circles are inverted southem hemisphere VGPs. Solid circle and open oval are the paleomagnetic pole and confidence region.

Plateau and poles from other regions. The findings of these studies are summarized in Figure 9. The hachured region of Figure 9 indicates an approximate "consensus" value of rotation.

The studies of Hamilton [1981] and Bryan and Gordon $[1986,1990]$ essentially reach the same conclusion: $3^{\circ}-5^{\circ}$ of post-Triassic clockwise Colorado Plateau rotation with respect to North America east of the Rio Grande Rift. Steiner [1988] suggests that the Colorado Plateau experienced a Late Permian motion involving $9.5^{\circ}$ of northward and $5.4^{\circ}$ of westward translation followed by a clockwise Laramide rotation of $11^{\circ}$. However, geologic evidence precludes these large displacements. For example, rifts, compressional structures, and large offset of the Paleozoic continental shelf required by the large Permian motions are not observed in the geologic record.

The discrepancy between the "pole-to-pole" analysis of Steiner [1986, 1988] and other analyses of Colorado Plateau rotation is probably due to uncertainties in the ages of paleomagnetic poles being compared. Figure 10 shows that younger Triassic poles are expected to be farther west on the APW path than older Triassic poles (assuming the PermianTriassic progression of Gordon et al. [1984] or Irving and Irving [1982]). Thus, if a Triassic paleomagnetic pole from the Colorado Plateau is compared with an older Triassic pole from another region of North America, a clockwise rotation of the plateau would be inferred. In fact, an age difference between the paleomagnetic poles from the Moenkopi and Red Peak formations may explain the $11^{\circ}$ post-Triassic clockwise rotation of the Colorado Plateau concluded by Steiner [1986, 1988].

If these poles are coeval, $11.7^{\circ} \pm 3.7^{\circ}$ of Colorado Plateau rotation can be inferred. However, the simple comparison of paleomagnetic poles in Figure 10 is misleading. In Figure 11, paleomagnetic data from the Moenkopi and Red Peak formations are displayed as sets of VGPs. The VGPs from the Red Peak Formation are from Van der Voo and Grubbs [1977], and the Moenkopi VGPs (each representing the mean from a polarity zone) are from Helsley and Steiner [1974]. Data from paleomagnetic studies without detailed thermal demagnetization, from publications where VGPs are not reported, or from borehole studies are not used [e.g., Helsley, 1969; Baag and Helsley, 1974; Purucker et al., 1980; Shive et al., 1984].

Figure $11 \mathrm{c}$ shows longitudinal streaks in both sets of VGPs, with Moenkopi Formation VGPs displaced westward relative to VGPs from the Red Peak Formation. As presented by Shive et al. [1984], a magnetostratigraphic correlation of the Moenkopi and Red Peak formations suggests that much of the Moenkopi Formation strata sampled by Helsley and Steiner [1974] are above the layer correlated with the Alcova Limestone. However, the majority of sites collected by Van der Voo and Grubbs were from stratigraphic levels below the 
TABLE 4. Mean Directions and Paleomagnetic Poles

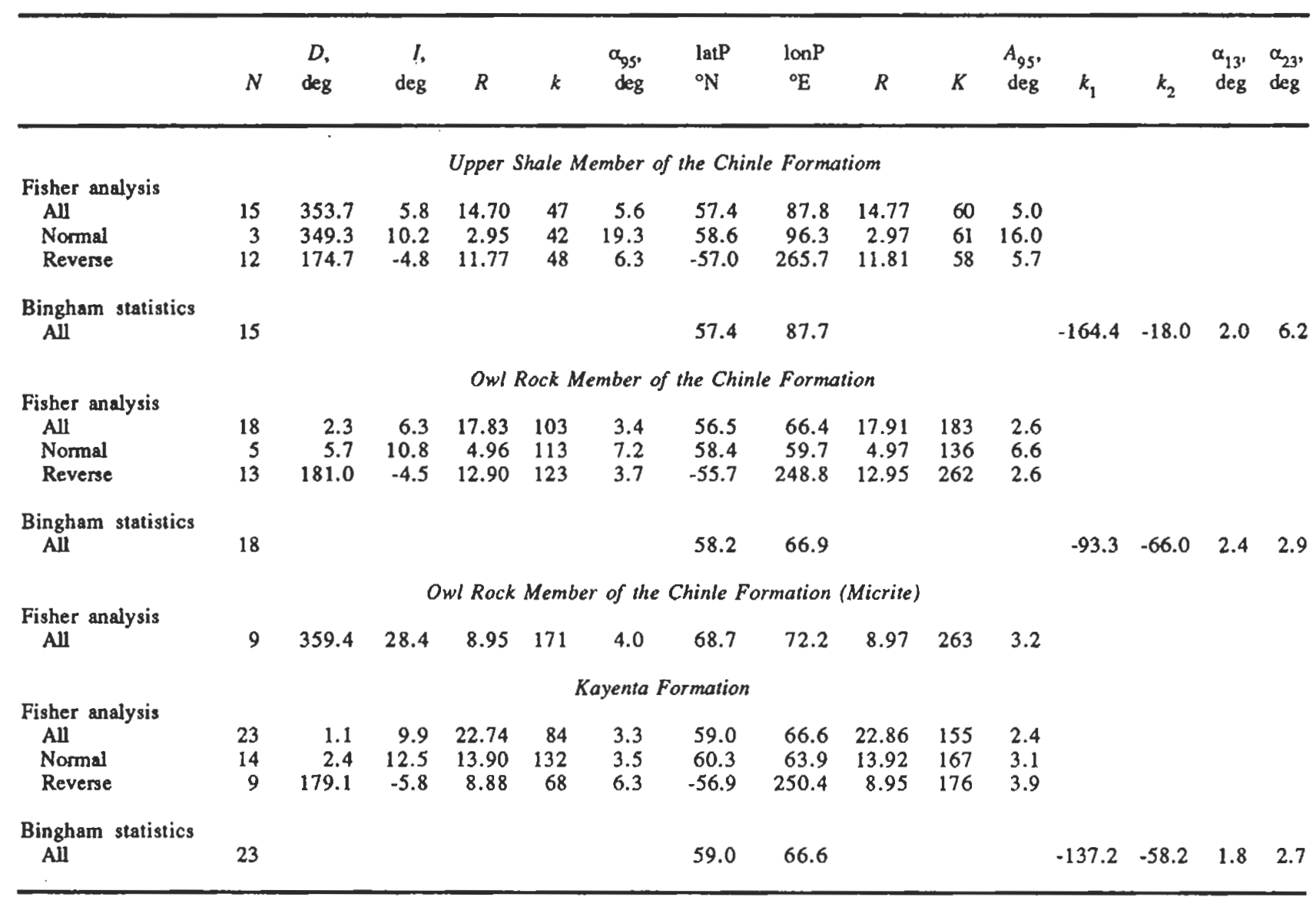

$N$, number of sites; $D$, formation mean declination; $l$, formation mean inclination; $R$, length of $N$ resultant unit vectors; $k, K$, estimate of Fisher precision parameter, $\alpha_{95}$ and $A_{95}$, radius of cone of $95 \%$ confidence about formation mean direction $\left(\alpha_{95}\right)$ or pole $\left(A_{95}\right)$; latP, latitude of formation paleomagnetic pole; lonP, longitude of formation paleomagnetic pole; $k_{1}$ and $k_{2}$, Bingham concentration parameters; $\alpha_{13}$ and $\alpha_{23}$, Bingham $95 \%$ confidence limits about the mean pole.

Alcova Limestone. Rather than comparing the entire distributions of VGPs, a more appropriate comparison can be made between VGPs from zones R3a to N4 of the Moenkopi Formation (high within-zone dispersion preclude using the data of Helsley [1969] in this comparison) with VGPs from sites 3 through 6 of the Red Peak Formation (Figure $11 b$ ). These two sets of VGPs are, in fact, indistinguishable at the $5 \%$ significance level.

Our evaluation of the Moenkopi-Red Peak comparison illuminates complications inherent in pole-to-pole comparisons. The magnetostratigraphic correlation shown in Figure $11 a$ may be equivocal, but it demonstrates the tenuous nature of this comparison. If the Moenkopi-Red Peak comparison does not require an $11^{\circ}$ clockwise rotation of the Colorado Plateau, then perhaps Steiner's [1988] alternate explanation of $6.6^{\circ}$ ( \pm 3.9 ) rotation resulting from comparison of late Paleozoic poles is correct. Interestingly, an averaged value of most of the estimates of Colorado Plateau rotation (i.e., the late Paleozoic comparison of Steiner [1988], Steiner et al. [1988], the Moenkopi-Red Peak comparison of Figure $11 b$; Hamilton [1981], and Bryan and Gordon [1986, 1990]) indicates clockwise rotation by approximately $4^{\circ}$. Therefore we use a correction for $4^{\circ}$ of clockwise rotation of the Colorado Plateau about an Euler pole located at $37^{\circ} \mathrm{N}, 257^{\circ} \mathrm{E}$ [Bryan and Gordon, 1986] in the following discussion of Late TriassicEarly Jurassic APW.

\section{DisCUSSION AND CONCLUSIONS}

\section{Chinle Poles}

Paleomagnetic poles from the members of the Chinle Formation provide a data base for evaluating late Carnian through middle Norian APW. Paleomagnetic poles from the Shinarump, Upper Shale, Owl Rock, Redonda, and Church Rock Members of the Chinle Formation are plotted in Figure $12 a$ and listed in Table 5. The Owl Rock and Church Rock Member poles have been corrected for $4^{\circ}$ of clockwise Colorado Plateau rotation. The Shinarump pole is taken from the recent work of Molina-Garza et al. [1990] on the lower portion of the Chinle Formation in central New Mexico. The Redonda pole was recalculated from Reeve and Helsley's [1972] upper and middle normal-polarity intervals, and the Church Rock pole was taken from Reeve's [1975] "top" Temple Mountain section. Because the Redonda and Church Rock poles are derived from data sets with only one polarity, a reversals test cannot be employed. Furthermore, neither investigation routinely demagnetized samples to temperatures above $630^{\circ} \mathrm{C}$. Therefore these poles may be less definitive than the Shinarump, Upper Shale, or Owl Rock poles. Additional poles presented by Reeve and Helsley [1972] and Reeve [1975] are not considered due to lack of resolution (Fisher $k$ values $<20$ ). 


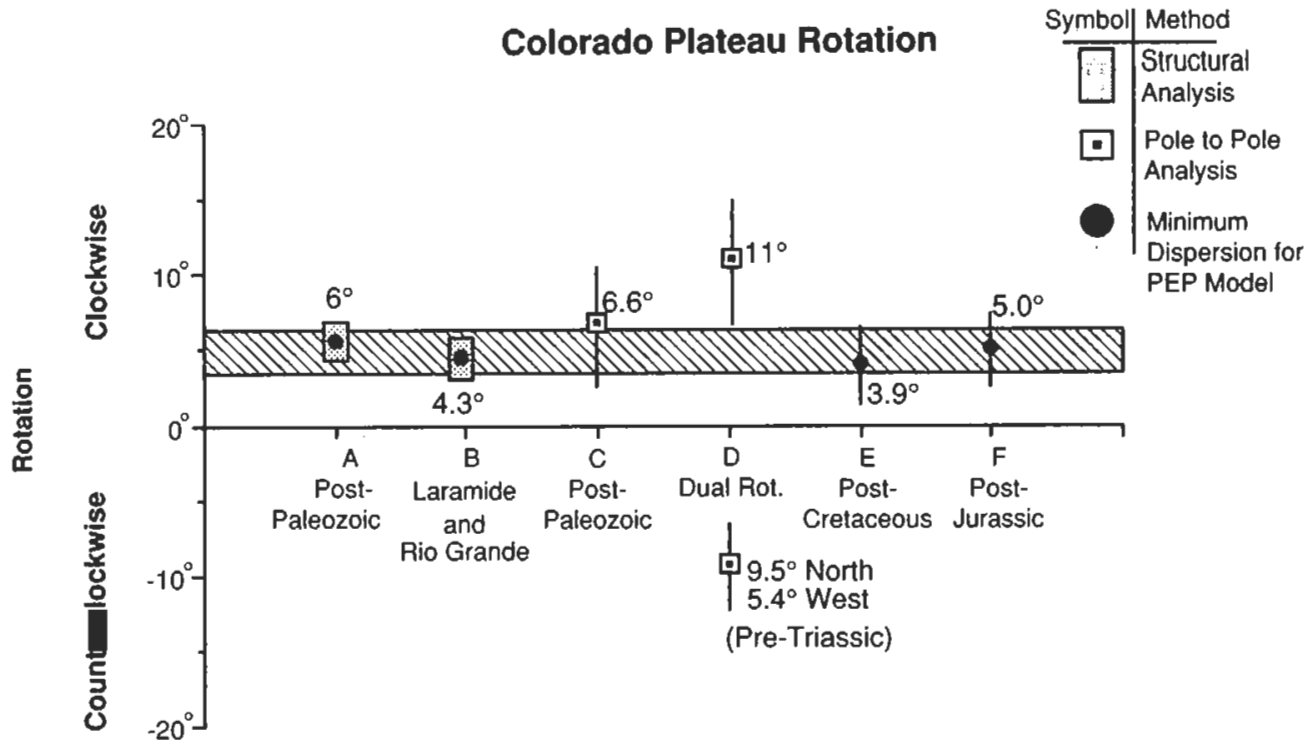

Fig. 9. Summary of Colorado Plateau rotation studies. References are given on the horizontal axis and amounts of rotation (either clockwise or counterclockwise) are given on the vertical axis. Amounts of rotation for each study are shown as solid symbols (circles or squares), with errors for each shown by vertical lines or extended boxes. The hachured region indicates an approximate "consensus value" including results of most analyses. The inconsistency of study D is discussed in the text. A, Hamilton [1981]; B, Hamilton [1981] and Cordell [1982]: C, Steiner [1988] (late Paleozoic data only); D, Steiner [1988] (late Paleozoic and Mesozoic data); E, Bryan and Gordon [1986]; F, Bryan and Gordon [1990].

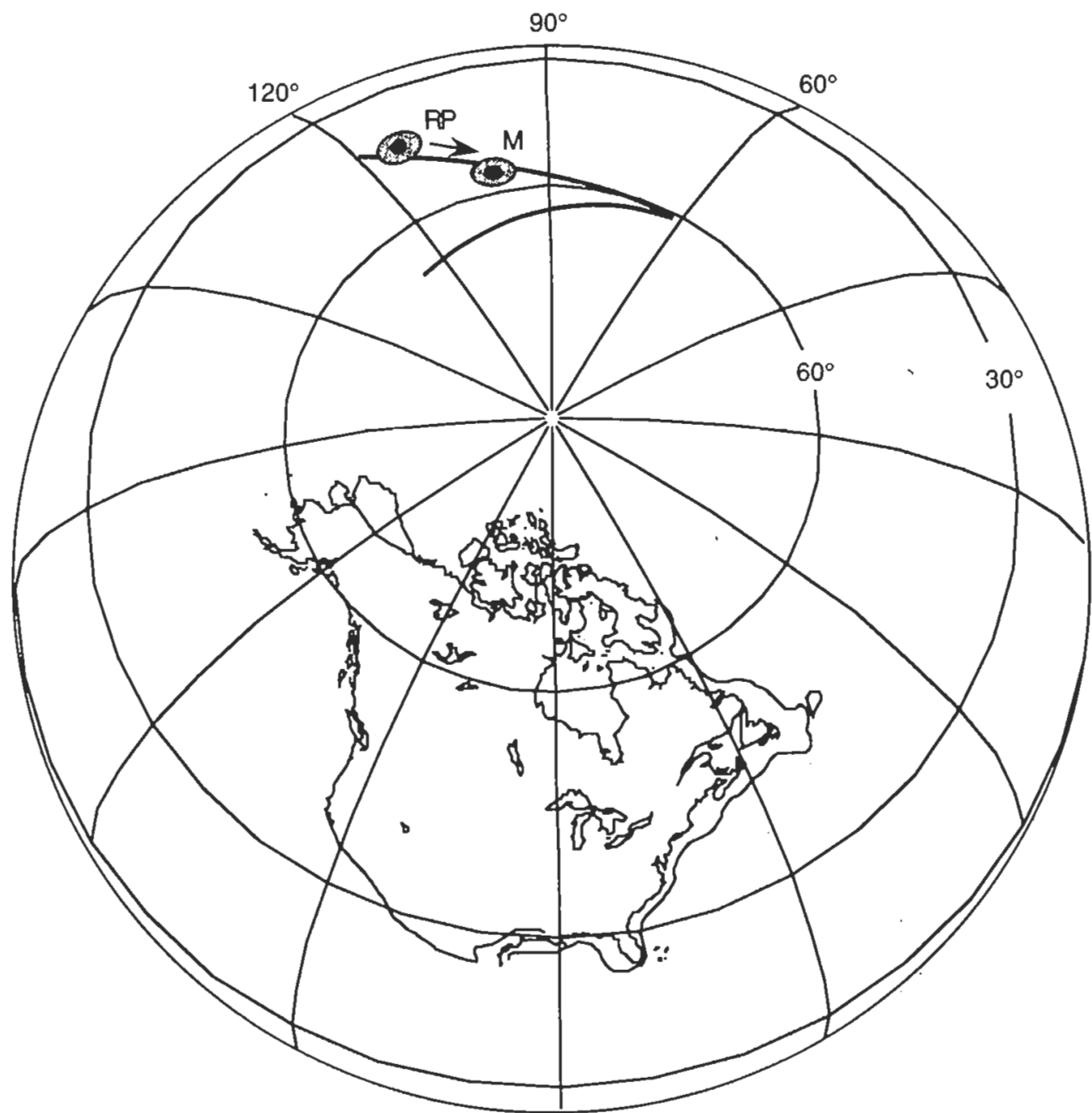

Fig. 10. Comparison of paleomagnetic poles from the Red Peak (RP) and the Moenkopi Formations (M) (modified from Steiner [1986]). The bold line represents the Late Triassic-Early Jurassic APW path [Gordon et al., 1984]. The arrow indicates the Moenkopi pole is rotaled relative to the Red Peak pole. The Moenkopi pole lies on a younger portion of the Mesozoic APW path than the Red Peak pole. See text for discussion. 


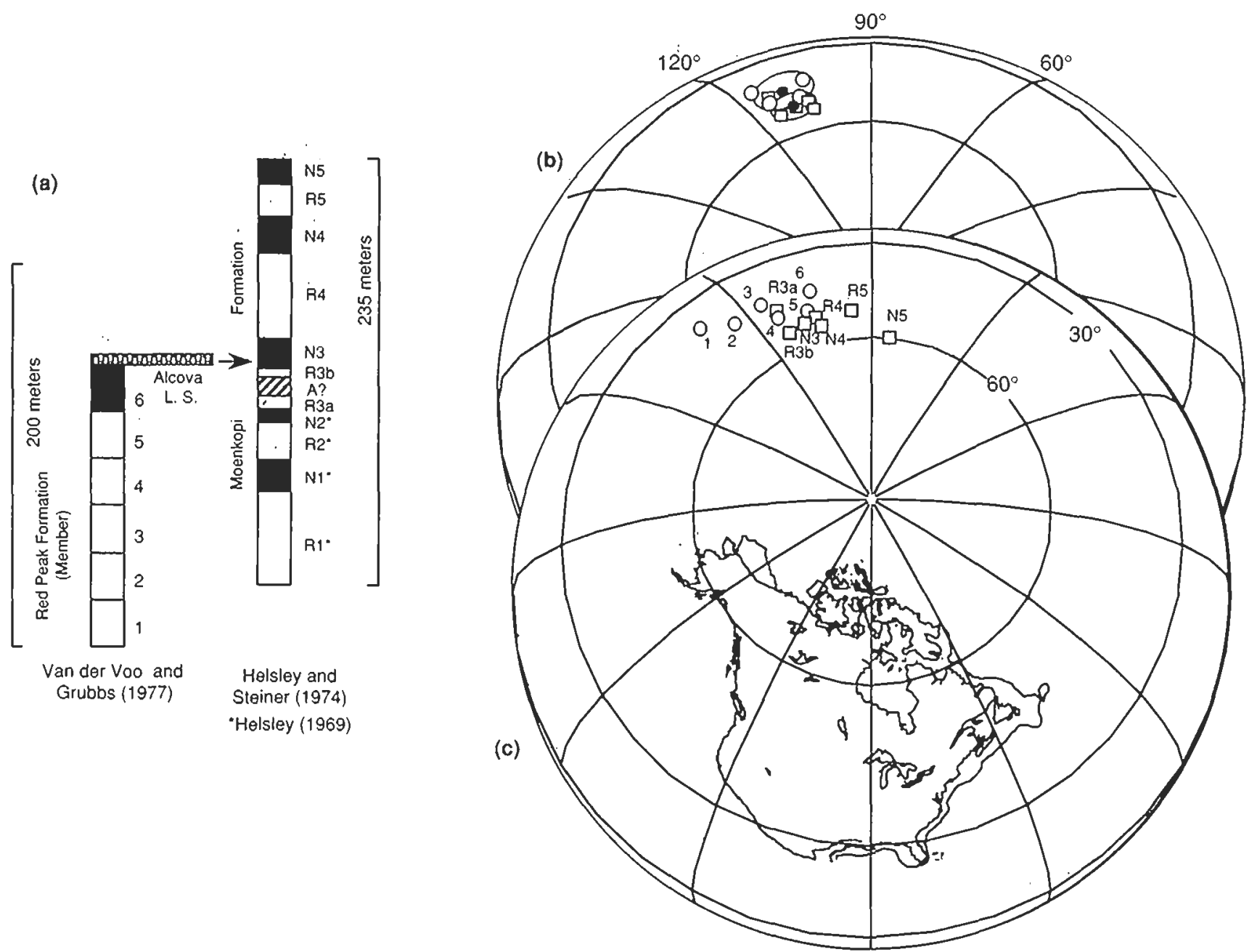

Fig. 11. Comparison of site-mean VGPs from the Red Peak and Moenkopi formations. (a) Polarity stratigraphy and relative position of paleomagnetic sites used to calculate VGPs. The arrow indicates the magnetostratigraphic correlation proposed by Shive et al. [1984]. Asterisks indicate polarity zones from Helsley [1969]. High within zone dispersion preclude using these data in Figures $I 1 b$ and $11 c$. (b) Selected Red Peak Formation (open circles) and Moenkopi Formation (open squares) site-mean VGPs (VGPs 1,2, N5, R5 are excluded). Paleomagnetic poles (solid circles) calculated from the selected VGPs of each formation are shown with $95 \%$ confidence limits. (c) Site-mean VGPs from the Red Peak Formation (open circles) [Van der Voo and Grubbs, 1977] and the Moenkopi Formation (open squares) [Helsley and Steiner, 1974].

The relative ages of these Chinle poles are determined by their stratigraphic position (Figure 13) and the assumption that depositional ages are equivalent to magnetization ages. This assumption appears valid for the Shinarump, Upper Shale, and Owl Rock members because data sets from these members pass reversals tests and within-site ChRM directions are well grouped. Stratigraphic superposition on the Colorado Plateau shows the Owl Rock Member to be older than the Church Rock Member but younger than the Petrified Forest and Shinaruinp members (Figure 13). In New Mexico, the Shinarump Member is stratigraphically beneath the Upper Shale Member, which in turn is overlain by the Redonda Member. Vertebrates, ostracodes, and charophytes indicate the Upper Shale of New Mexico correlates with most of the upper portion of the Petrified Forest Member ( $S$. G. Lucas, written communication, 1989). In addition, the Redonda Member in New Mexico is equivalent to much of the Church Rock Member of the Colorado Plateau (S. G. Lucas, written communication, 1989). Thus the Owl Rock Member is younger than the Upper Shale Member and probably equivalent to lower portions of the Redonda Member.
These age relationships require decreasing age within the Chinle Formation as follows: Shinarump, Upper Shale, Owl Rock, Redonda/Church Rock. If APW progressed westward during this time interval (as proposed by Irving and Irving [1982]; Gordon et al. [1984], and May and Buller [1986]), then progressively younger Chinle member poles should be located at progressively more westerly longitudes. This trend is observed in a general sense with the Shinarump and Upper Shale member poles located to the east of poles from the younger Owl Rock, Redonda, and Church Rock members (Figure 12a). However, the older Shinarump pole is expected to be east of the Upper Shale pole, yet it is essentially at the same longitude (Table 5). This suggests either little APW during this time period or a problem with determination of these pole positions. Because the Shinarump pole was calculated from samples collected near the Rio Grande Rift, it is possible that local or regional rotations may have affected magnetization directions. Molina-Garza el al. [1990] have proposed the sampling region is structurally linked with the Colorado Plateau and consequently also has been rotated $4^{\circ}$ clockwise. Correction of the Shinarump Member pole for 


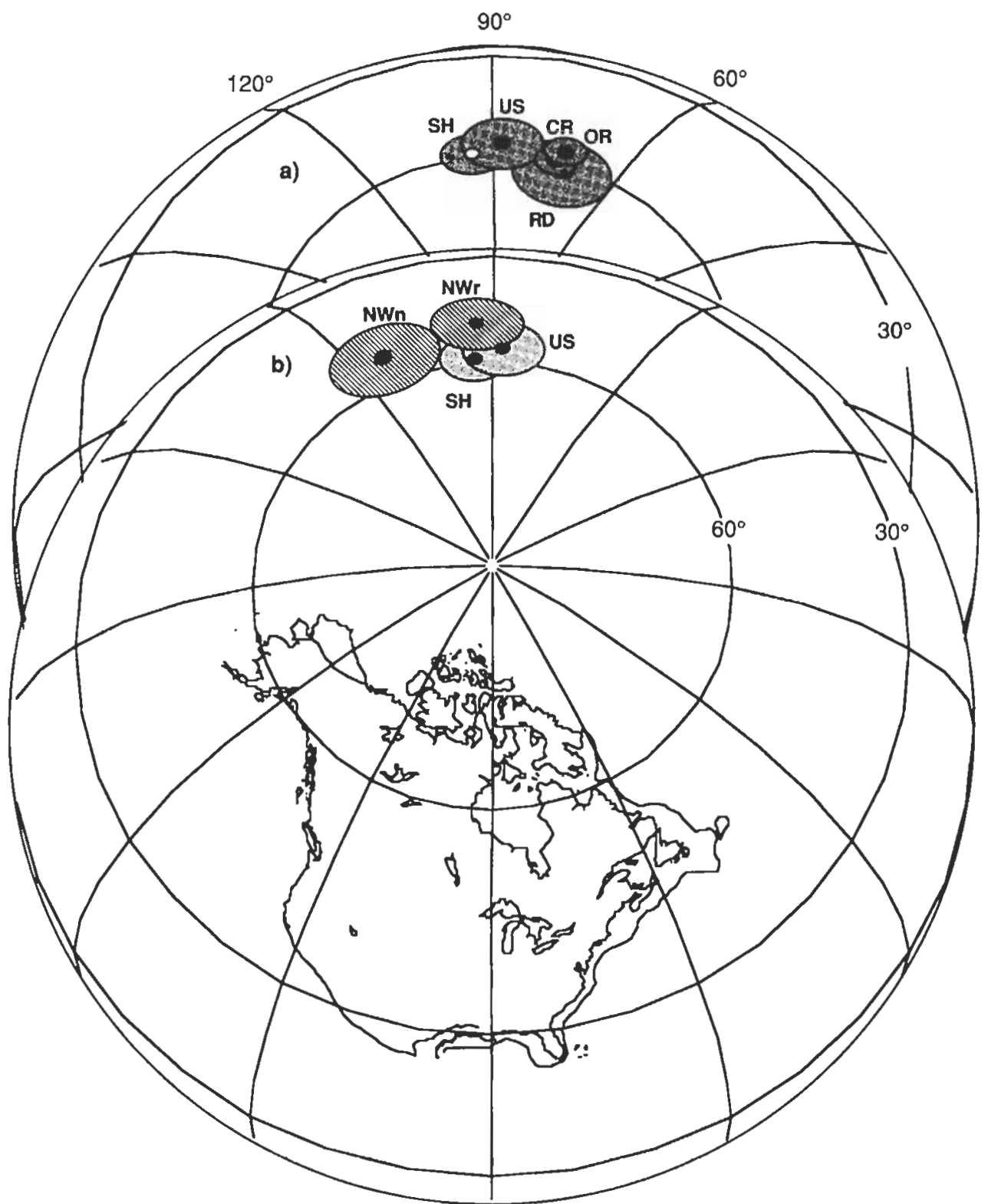

Fig. 12. (a) Paleomagnetic poles from five members of the Chinle Formation. SH, Shinarump Member (Molina-Garza et al., 1990]; US, Upper Shale Member (this study); RD, Redonda Member (recalculated from Reeve and Helsley [1972]); OR, Owl Rock Member (this study): CR. Church Rock Member (Reeve, 1975). SH, OR, and CR were corrected for $4^{\circ}$ clockwise rotation of the Colorado Plateau. (b) North American middle Camian to early Norian paleomagnetic poles. NW, Stockton, Lockatong, and Passaic Formations of the Newark Basin, Pennsylvania [Witte and Kent, 1989a]: NWn, mean of normal-polarity data; NWr, mean of reverse-polarity data. US and SH are the same as for Figure 12a. Each pole is surrounded by its $95 \%$ confidence limit.

this rotation results in the pole position shown in Figure $12 a$ (pole $\mathrm{SH}$ ) and thus results in a systematic westward progression of paleomagnetic poles.

The discrepancy of the Shinarump and Upper Shale member paleomagnetic pole positions also may be due to problems associated with determining the Upper Shale pole. As noted above the Upper Shale VGP distribution is non-Fisherian. The Bingham statistics for the Upper Shale pole describe a confidence region (Table 4) elongated parallel to longitude which includes the region west of the Shinarump pole. Considering this confidence region, it can be argued that the Chinle poles display a trend consistent with a constant rate of APW with decreasing age.

been isolated in the Carnian to early Norian Stockton, pole, eight of the 19 site-mean VGPs have precision parame-
Lockatong, and Passaic formations of the Newark Basin [Witte and Kent, 1989a]. Palynological and vertebrate fossil studies suggest a similar latest Carnian-early Norian age for the Passaic Formation and the Upper Petrified Forest Member of the Chinle Formation [Litwin, 1986; Long and Padian, 1986]. The age equivalence of the Upper Shale Member and Upper Petrified Forest member of the Chinle Formation (S. G. Lucas, personal communication, 1989) implies that the Upper Shale pole should agree with the Newark pole. Instead the Newark pole lies east of the Upper Shale pole as well as the pole from the Shinarump Member of the Chinle

mation (Figure 14b) 
TABLE 5. Camian-Norian Paleomagnetic Poles

\begin{tabular}{|c|c|c|c|c|c|c|c|}
\hline Unit & Age & $\begin{array}{l}\text { latP, } \\
{ }^{\circ} \mathrm{N}\end{array}$ & $\begin{array}{l}\text { lonp, } \\
{ }^{\circ} \mathrm{E}\end{array}$ & $\begin{array}{r}A_{95} \\
\text { deg }\end{array}$ & $k$ & $N$ & Reference \\
\hline \multicolumn{8}{|l|}{ Chinle Formation } \\
\hline Shinarump Member* & Camian & $\begin{array}{l}60.0 \\
(59.2\end{array}$ & $\begin{array}{l}87.0 \\
94.7)\end{array}$ & 4.0 & 132 & - & 1 \\
\hline Upper Shale Member & earliest Norian & 57.4 & 87.8 & 5.0 & 60 & 15 & 2 \\
\hline Owl Rock Member* & middle Norian & $\begin{array}{l}56.5 \\
(56.9\end{array}$ & $\begin{array}{l}66.4 \\
73.6)\end{array}$ & 2.6 & 183 & 18 & 2 \\
\hline Redonda Member & mid-late Norian & 61.4 & 72.4 & $\begin{array}{c}6.0^{\dagger} \\
(3.5 / 6.9)\end{array}$ & 22 & $\begin{array}{c}2^{\ddagger} \\
(83)\end{array}$ & 3,2 \\
\hline Church Rock Member* & mid-late Norian & $\begin{array}{l}59.0 \\
(59.3\end{array}$ & $\begin{array}{l}67.0 \\
74.7)\end{array}$ & $\begin{array}{c}2.5^{\dagger} \\
(1.7 / 3.3)\end{array}$ & 72 & $\begin{array}{c}1^{\ddagger} \\
(28)\end{array}$ & 4,2 \\
\hline $\begin{array}{l}\text { Newark Sediments } \\
\text { Nomal } \\
\text { Reverse }\end{array}$ & Camian/Norian & $\begin{array}{l}53.5 \\
54.9 \\
51.8\end{array}$ & $\begin{array}{c}101.6 \\
113.4 \\
93.6\end{array}$ & $\begin{array}{l}4.8 \\
6.8 \\
5.7\end{array}$ & $\begin{array}{l}50 \\
68 \\
64\end{array}$ & $\begin{array}{r}19 \\
8 \\
11\end{array}$ & 5 \\
\hline
\end{tabular}

Age, geologic time scale of Harland et al. [1990]; latP, latitude of paleomagnetic pole; lonP, longitude of paleomagnetic pole; $A_{95}$, radius of cone of $95 \%$ confidence about paleomagnetic pole; $k$, estimate of Fisher precision parameter; $R$, length of resultant of $N$ unit vectors; $N$, number of sites; references: 1, Molina-Garza et al. [1990]; 2, this study; 3, Reeve and Helsley [1972]; 4, Reeve [1975]: 5, Witte and Kent [1989]. Dash indicates data not listed in reference.

*Poles in parentheses have been corrected for $4^{\circ}$ of clockwise rotation of the Colorado Plateau.

†Estimated $A_{95}, d p$ and $d m$ are given in parentheses.

Number of polarity zones; number of specimens given in parentheses.

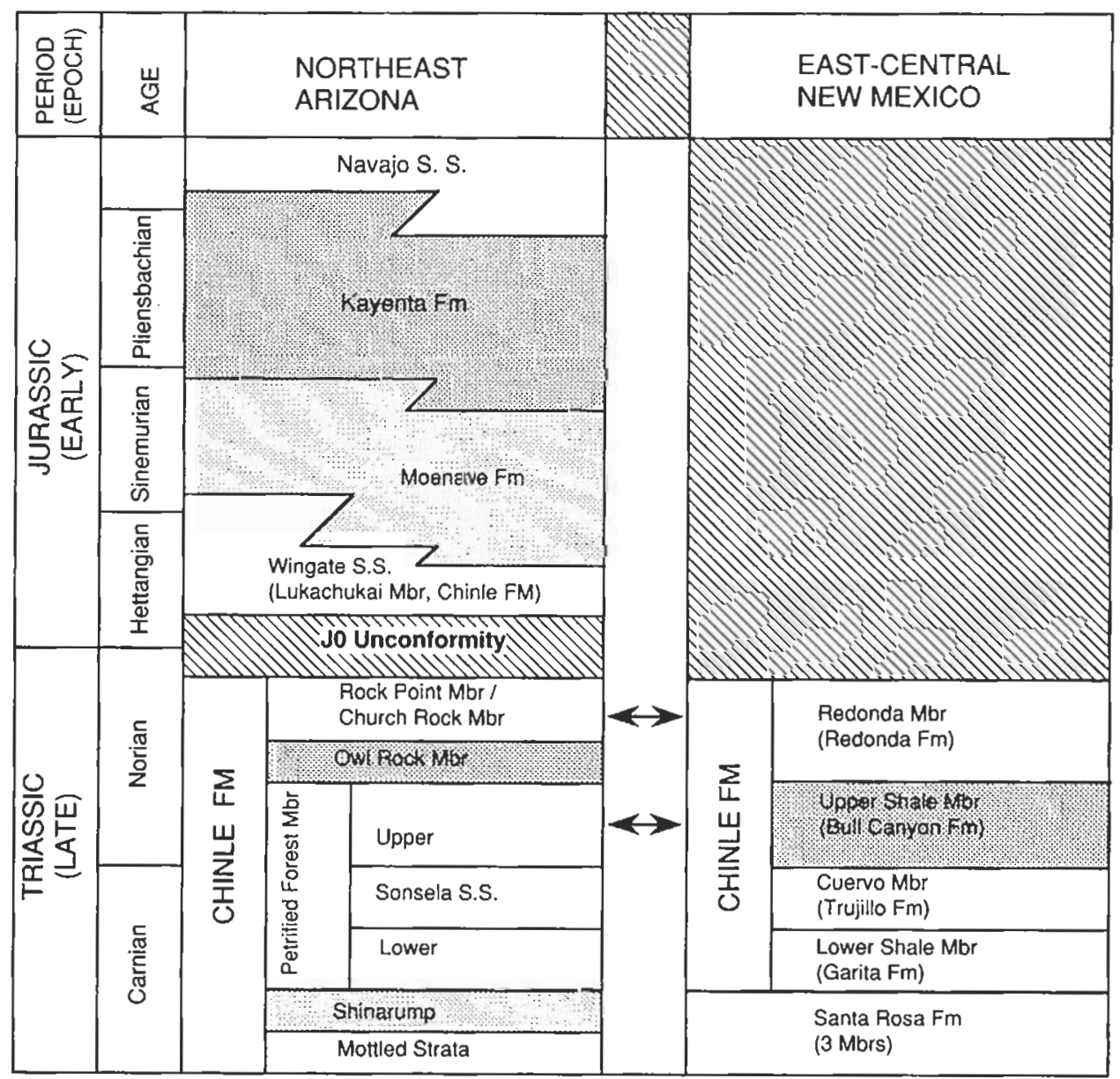

Fig. 13. Stratigraphy of the Late Triassic-Early Jurassic sediments of northeast Arizona and east central New Mexico. Double-sided arrows indicate correlations discussed in the text. Stratigraphy and correlations from Pipiringos and O'Sullivan [1978], Lucas et al. [1985], and Lucas and Hunt [1989]. Modified from Lucas et al. [1985]. 


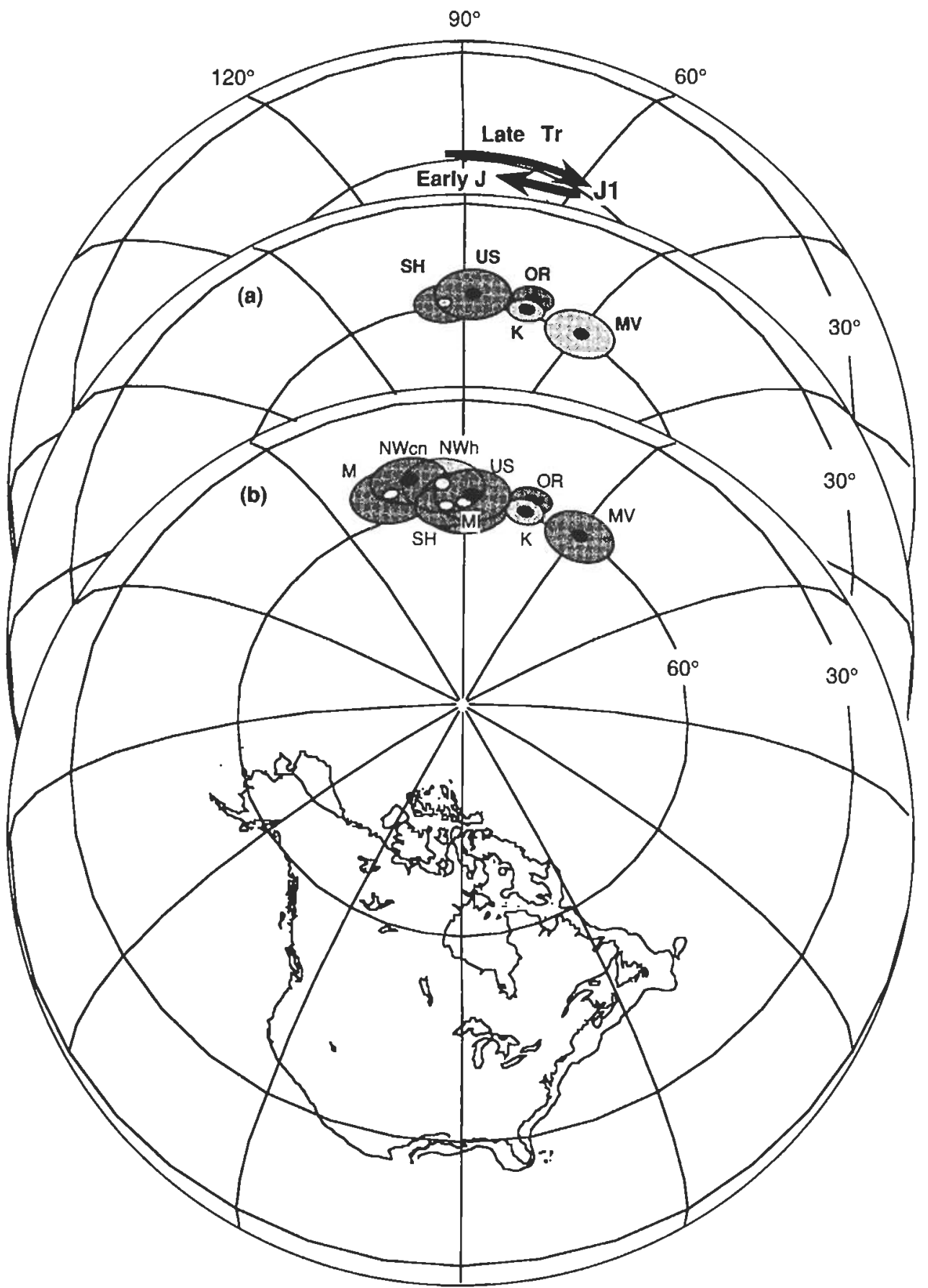

Fig. 14. (a) Late Triassic-Early Jurassic paleomagnetic poles from sedimentary rocks of the southwestern United States. SH, Shinarump Member of the Chinle Formation [Molina-Garza et al., 1990]; US, Upper Shale Member of the Chinle Formation (this study); OR, Owl Rock Member of the Chinle Formation (this study); MV, Moenave Formation (Ekstrand and Butler, 1989]; K, Kayenta Formation (this study). (b) Poles of Figure 14a in addition to other selected Triassic-Early Jurassic paleomagnetic poles for North America. M, Moenkopi Formation [Helsley and Steiner, 1974]; NWcn, Stockton, Lockatong, and Passaic formations of the Newark Basin [Witte and Kent, 1989a]; NWh, Hettangian sedimentary rocks of the Newark Basin [Witte and Kent, 1990]; MI, Manicouagan Impact Structure [Robertson, 1967; Larochelle and Currie, 1967]; M, SH, OR, MV, and $\mathrm{K}$ have been corrected for $4^{\circ}$ of clockwise rotation of the Colorado Plateau (see Table 6 for both corrected and uncorrected pole positions). Each pole is surrounded by its $95 \%$ confidence limit. The trend of Late Triassic-Early Jurassic APW is shown by the bold arrows on the othographic projection underlying Figure $14 a$.

ters (Fisher's $k$ ) less than 20 and/or $\alpha_{95} s>20^{\circ}$. Also, the means of normal- and (inverted) reverse-polarity VGPs differ by $13^{\circ}$, resulting in failure of the reversals test at the $5 \%$ significance level. It is interesting to note that the mean of the (inverted) reverse-polarity Newark VGPs (lonP, $93.6^{\circ} \mathrm{E}$,
latP, $51.8^{\circ} \mathrm{N}$; NWr, Figure $12 b$ ) is closer to the Upper Shale pole (lonP, $87.8^{\circ} \mathrm{E}$, latP, $57.4^{\circ} \mathrm{N}$; US, Figure $12 \mathrm{~b}$ ) and the Shinarump pole (lonP, $87^{\circ} \mathrm{E}$, latP, $60^{\circ} \mathrm{N}$; SH, Figure $12 b$ ) than the mean of the normal-polarity Newark VGPs (lonP, $113.4^{\circ} \mathrm{E}$, latP, $54.9^{\circ} \mathrm{N}$; NWn, Figure $12 b$ ). Furthermore, 
Newark reverse-polarity data are consistent with the westward progression of APW described by the Chinle poles (Figure 12).

On the other hand, the elliptical distribution of Upper Shale VGPs allows the possibility of long-term remanent magnetization acquisition. Therefore, the earliest Norian pole may lie toward the most eastern longitude portion of the Bingham confidence region of the Upper Shale pole (Table 4). Even so, the mean of the normal-polarity Newark VGPs is substantially east of both this confidence region and the position of the Shinarump pole (even after the Shinarump pole is corrected for $4^{\circ}$ of clockwise Colorado Plateau rotation). Witte and Kent [1989a] argued that remagnetization is not a viable explanation for the position of the Newark VGPs because they do not fall in a region occupied by post-Carnian paleomagnetic poles. However, it is possible that some of these sites have been affected by tectonic disturbance similar to that reported by Van Fossen et al. [1986]. In addition, resultant vectors produced by combining normal- and reversepolarity Late Triassic magnetizations could account for aberrant longitude positions of either Newark or Upper Shale VGPs.

In addition to explanations involving the reliability of the paleomagnetic poles, effects of the nondipole portion of the geomagnetic field could be a cause for this conflict between the Chinle and Newark data. Nondipole effects may have resulted in poles from one region being far-sided relative to poles from elsewhere in North America. However, this speculation is not testable with the currently available paleomagnetic data.

\section{Late Triassic-Early Jurassic Paleomagnetic Poles From} the Southwestern United States

In contrast to some poles used in previous analyses of Late Triassic-Early Jurassic APW, the paleomagnetic poles from the southwestern United States shown in Figure 14a were all determined from 15 or more site-mean VGPs, which pass the reversals test. These data allow better resolution of pole positions, as reflected in the small $95 \%$ confidence regions. Paleomagnetic poles calculated from Mesozoic sediments of the southwestern United States considered unreliable by $M a y$ and Butler [1986] have been excluded from our analysis. In addition, if more than one pole of a particular age has been determined, the better resolved pole is used in this analysis. In particular, the Chinle poles of Reeve and Helsley [1972] and Reeve [1975] are excluded in favor of the Shinarump Member, Upper Shale Member, and Owl Rock Member poles. Previous determinations of the Kayenta paleomagnetic pole [i.e., Johnson and Nairn, 1972; Sleiner and Helsley, 1974] also are excluded in favor of the paleomagnetic pole from the Kayenta Formation reported here. The Wingate Sandstone pole [Reeve, 1975] is excluded due to large uncertainties associated with its determination $(k=6.1)$. Instead, the paleomagnetic pole from the essentially age equivalent Moenave Formation [Ekstrand and Butler, 1989] is used.

A Late Triassic-Early Jurassic APW path can be constructed entirely of paleomagnetic poles from sedimentary rocks of the southwestern United States. The stratigraphic succession consisting of the Chinle, Moenave, and Kayenta formations encompasses $\sim 30$ m.y. from earliest Norian through Pliensbachian age (Figure 13 and Table 6). As discussed above, paleomagnetic poles from the Chinle Formation exhibit a progressive westward shift in longitude with decreasing age. This systematic trend continues until magnetization of Hettangian-Sinemurian Moenave strata (pole MV in Figure 14a). By the time the Pliensbachian Kayenta strata are magnetized (pole $\mathrm{K}$ in Figure $14 a$ ), the APW path has turned a comer and is progressing toward more easterly longitudes.

This APW pattern defines a sharp cusp (the J1 cusp proposed by Gordon et al. [1984] and May and Butler [1986]) in the Mesozoic APW path. The Jl cusp is located near the paleomagnetic pole from the Moenave Formation, and thus its age is approximately Hettangian to Pliensbachian (approximately 208 to $195 \mathrm{Ma}$ ). The $\mathrm{J} 1$ cusp is defined most clearly by paleomagnetic poles from the Colorado Plateau. So, defining the position of the J1 cusp with respect to other portions of North America is dependent on accurate correction for Colorado Plateau rotation. The $\mathrm{J} 1$ cusp poles of Figure $14 a$ have been corrected for the $4^{\circ}$ of clockwise Colorado Plateau rotation, discussed above. However, even if different Colorado Plateau rotations are used, the geometry of the J1 cusp is retained because all poles used to determine the geometry must be corrected by an equal amount. Therefore Colorado Plateau rotation is a factor in controlling the exact location of the $J 1$ cusp, but the existence of the $J 1$ cusp as a major feature of North American Mesozoic APW seems quite certain.

\section{Late Triassic-Early Jurassic APW}

The three paleomagnetic poles reported here and other North American Late Triassic-Early Jurassic paleomagnetic poles allow refinement of the North American Late TriassicEarly Jurassic APW path. Figure $14 b$ shows several poles (Table 6) deemed reliable using the criteria of May and Butler [1986]. All poles calculated from rocks of the Colorado Plateau (Moenkopi, Shinarump, Owl Rock, Moenave, Kayenta) have been corrected for $4^{\circ}$ of clockwise rotation.

Paleomagnetic poles from the Newark trend igneous rocks [Smith and Noltimier, 1979] (labeled N1 and N2 poles by May and Butler [1986]) are not included in Figure 14b. Recent analysis of the $\mathrm{N} 1$ data by Prevot and McWilliams [1989] indicates the 72 VGPs used to determine the N1 pole may represent only seven independent samplings of the Jurassic magnetic field. This observation and the fact that nearly all Newark trend magnetizations are of normal polarity [Smith and Noltimier, 1979] suggested that these poles may not represent adequate averages of paleosecular variation. Furthermore, Wilte and Kent [1990] suggest the magnetizations of the Newark igneous rocks may be biased by a steeper overprint. The ages of the $\mathrm{N} 1$ and $\mathrm{N} 2$ intrusives and extrusives also have been questioned [Wilte and Kent, 1990; Sutter, 1988; Seideman et al., 1984]; these igneous rocks may have been affected by later thermal events [Sutter, 1988] or inherited argon [Seidemann et al., 1984]. Moreover, geochemical data suggest the N1 and N2 igneous units are of similar age [Ratcliffe, 1988; Phillpotts and Martello, 1986], but their magnetizations yield distinct paleomagnetic poles. Thus the status of the $\mathrm{N} 1$ and N2 poles is in question.

Paleomagnetic poles from diabase dikes of North Carolina [Smith, 1987] and plutons of Maine [ $W u$ and Van der Voo, 1988] are not shown in Figure $14 b$ but are listed in Table 6. The two poles obtained by $S m i t h$ [1987] are from diabase dikes yielding a wide range of $\mathrm{K}$-Ar dates (>200-180 Ma). However, the older of the two poles (North Carolina Dikes, Table 6) is statistically indistinguishable (at the $5 \%$ significance level) from the Moenave Formation pole. Thus the more westerly longitude APW path segment described by poles from the southwestern United States also may be recorded in rocks of eastern North America. Better determination of the ages of these dikes should allow evaluation of this possibility.

More reliable $\mathrm{K}$-Ar dates have been obtained from two Maine plutons studied by $W u$ and Van der Voo [1988] (221 \pm 8 and $228 \pm 5 \mathrm{Ma}$ ). Although $\mathrm{Wu}$ and $V$ an der Voo suggest 
Baag, C., and C. E. Helsley, evidence for penecontemporaneous magnetization of the Moenkopi Formation, J. Geophys. Res., 79. $3308-3320,1974$.

Blakey, R. C., and R. Gubitosa, Late Triassic paleogeography and depositional history of the Chinle Fomation, southem Utah and northem Arizona, in Mesozoic Paleogeography of West.Central United States, edited by M. W. Reynolds and E. D. Dolly, Pp. 5776, Rocky Mountain Section, Society of Economic Paleontologists and Mineralogists, Denver, Colo., 1983.

Blakey, R. C., and R. Gubitosa, Controls of sandstone body geometry and architecture in the Chinle Formation (Upper Triassic), Colorado Plateau, Sediment. Geol., 38, 51-86, 1984.

Bryan, P., and R. G. Gordon, Rotation of the Colorado Plateau: An analysis of paleomagnetic data, Tectonics, 5, 661-667, 1986.

Bryan, P., and R. G. Gordon, Rotation of the Colorado Plateau: An updated analysis of paleomagnetic data, Geophys. Res. Letr., 17, 1501-1504, 1990.

Chase, C. G., and D. R. Sprowl, The modern geoid and ancient plate boundaries, Earth Planet. Sci. Letl., 62, 314-320, 1983.

Clark, J. M., and D. E. Fastovsky, Vertebrate biostratigraphy of the Glen Canyon Group in northem Arizona, in The Beginning of the Age of the Dinosaurs, edited by K. Padian, pp. 285-301, Cambridge University Press, New York, 1986.

Cordell, L., Extension in the Rio Grande rift, J. Geophys. Res., 87, 8561-8569, 1982.

Cornet, B., and A. Traverse, Palynological contribution to the chronology and stratigraphy of the Hartford basin in Connecticut and Massachusetts, Geoscience and Man, 11, 1-33, 1975.

Dickinson, W. R., PJate tectonic evolution of the southem Cordillera, Ariz. Geol. Soc. Dig., 14, 113-135, 1981.

Ekstrand, E. J., and R. F. Butler, Paleomagnetism of the Moenave Formation: Implications of the Mesozoic North American apparent polar wander path, Geology, 17, 245-248, 1989.

Fisher, R. A., Dispersion on a sphere, Proc. R. Soc. London, Ser. A, $217,295-305,1953$.

Gordon, R. G., A. Cox, and S. O'Hare, Paleomagnetic Euler poles and the apparent polar wander and absolute motion of North America since the Carboniferous, Tectonics, 3, 499-537, 1984.

Gumis, M., Large-scale mantle convection and the aggregation and dispersal of supercontinents, Nature, 332, 695-699, 1988.

Hamilton, W., Plate-tectonic mechanism of Laramide deformation, Contrib. Geol., 19, 87-92, 1981.

Hamilton, W., and W. B. Myers, Cenozoic tectonics of the western United States, Rev. Geophys., 4, 509-549, 1966

Harland, W. B., A. V. Cox, P. G. Llewellyn, C. A. G. Pickton, A. G. Smith, and R. Walters, A Geologic Time Scale, Cambridge University Press, New York, 1982.

Harland, W. B., R. L. Armstrong, A. V. Cox, L. E. Craig, A. G. Smith, and D. G. Smith, A Geologic Time Scale 1989, Cambridge University Press, New York, 1990.

Helsley, C. E., Magnetic reversal stratigraphy of the Lower Triassic Moenkopi Formation of westem Colorado, Geol. Soc. Am. Bull., $80,2431-2450,1969$

Helsley, C. E., and M. B. Steiner, Paleomagnetism of the Lower Triassic Moenkopi Formation, Geol. Soc. Am. Bull., 85, 457464, 1974.

Herrero-Bravera, E., and C. E. Helsley, Paleomagnetism of a polarity transition in the lower (?) Triassic Chugwater Formation. Wyoming, J. Geophys. Res., 88, 3506-3522. 1983.

Irving, E., Drift of the major continental blocks since the Devonian, Nature, 270, 304-309, 1977.

Irving, E., and G. A. Irving. Apparent polar wander paths, Carboniferous through Cenozoic and the assembly of Gondwana. Geophys. Surv., 5, 141-188, 1982.

Johnson, A. H., and A. E. M. Nairn, Jurassic paleomagnetism, Nature, $240,551-552,1972$.

Kirschvink, J. L., The least-squares line and plane and the analysis of paleomagnetic data: Examples from Siberia and Morocco, Geophys. J. R. Astron. Soc., 62, 699-718, 1980.

Kluth, C. F., R. F. Butler, L. E. Harding, M. Shafiqullah, and P. E. Damon, Paleomagnetism of late Jurassic rocks in the northern Canelo Hills, southeastern Arizona, J. Geophys. Res., 87, 7079. $7086,1982$.

Larochelle, A., and K. L. Currie, Paleomagnetic study of igneous rocks from the Manicouagan Structure, Quebec, J. Geophys. Res. 72, 4163-4169, 1967
Larson, E. E., T. R. Walker, P. E. Patterson, R. P. Hoblitt, and J. G. Rosenbaum, Paleomagnetism of the Moenkopi Formation, Colorado Plateau: Basis for long-term model of acquisition of chemical remanent magnetism in red beds, J. Geophys. Res., 87, 1081-1106, 1982.

Litwin, R. J., The palynostratigraphy and age of the Chinle and Moenave Formations, southwestern U.S.A., Ph.D. thesis, 265 pp., Penn State Univ., State College, 1986.

Long, R. A., and K. Padian, Vertebrate biostratigraphy of the Late Triassic Chinle Formation, Petrified Forest National Park, Arizona: Preliminary results, in The Beginning of the Age of Dinosaurs, edited by K. Padian, Pp. 161-169, Cambridge University Press, New York, 1986.

Lucas, S. G., and A. P. Hunt, Revised Triassic stratigraphy in the Tucumcar basin, east-central New Mexico, in Dawn of the Age of Dinosaurs in the American Southwest, edited by S. G. Lucas and A. P. Hunt, pp. 150-170, New Mexico Museum of Natural History, Albuquerque, New Mex., 1989.

Lucas, S. G., A. P. Hunt, and M. Morales, Stratigraphic nomenclature and correlation of Triassic rocks of east-central New Mexico: A preliminary report, Field Conf. Guideb. N. M. Geol. Soc., 36th, $171-184,1985$

Manspeizer, W., Triassic-Jurassic rifting and opening of the Atlantic: An overview, in Triassic-Jurassic Rifting, Continental Breakup and the Origin of the Atlantic Ocean and Passive Margins, Part A edited by W. Manspeizer, pp. 41-79. Elsevier, New York, 1988.

May, S. R., and R. F. Butler, North American Jurassic apparent polar wander: Implications for plate motion, paleogeography, and Cordille ran tectonics, J. Geophys. Res., 91, 11,519-11,544, 1986.

May, S. R, R. F. Butler, M. Shafiqullah, and P. E. Damon, Paleomagnetism of Jurassic volcanic rocks in the Patagonia Mountains, southeastern Arizona: Implications for the North American $170 \mathrm{Ma}$ reference pole, J. Geophys. Res., 91, 11,545. $11,555,1986$

May, S. R., M. E. Beck, and R. F. Butler, North American apparent polar wander, plate motion, and left-oblique convergence: Late Jurassic-Early Cretaceous orogenic consequences, Tectonics, 8 , 443-451, 1989

McFadden, P. L., The best estimate of Fisher's precision parameter $\mathrm{K}$, Geophys. J. R. Astron. Soc.. 61, 183-192., 1980.

McFadden, P. L., and F. J. Lowes, The discrimination of mean directions drawn from Fisher distributions, Geophys. J. R. Astron. Soc., 67, 19-33, 1981

McFadden, P. L., and M. W. McElhinny, A physical model for palaeosecular variation, Geophys. J.. R. Astron. Soc., 78, 809$830,1984$.

Molina-Garza, R. S., R. Van der Voo, and J. W. Geissman, Paleomagnetic data for the Shinarump Member of the Chinle Formation in central New Mexico (abstract), Eos Ttrans. AGU, 17. $488,1990$.

Olsen, P. E., N. H. Shubin, and M. H. Anders, New Early Jurassic Tetrapod assemblages constrain Triassic-Jurassic tetrapod extinction event, Science, 237, 1025-1029, 1987.

Onstott, T. C., Application of the Bingham distribution function in paleomagnetic studies., J. Geophys. Res., 85, 1500-1510, 1980.

Padian, K., Introduction, in The Beginning of the Age of Dinosaurs, edited by K. Padian, pp. 1-7, Cambridge University Press, New York, 1986a.

Padian, K., On the type material of Coelophysis Cope (Saurischia: Theropoda) and a new specimen from the Petrified Forest of Arizona (Late Triassic: Chinle Formation), in The Beginning of the Age of Dinosaurs, edited by K. Padian, pp. 45-60. Cambridge University Press, New York, $1986 b$.

Padian, K., Presence of the dinosaur Scelidosaurus indicates Jurassic age for the Kayenta Formation (Glen Canyon Group, northem Arizona), Geology, 17, 438-441, 1989.

Palmer, A. R., The decade of North American geology, 1983 geologic time scale, Geology, II, 503-504, 1983.

Peterson, F., and G. N. Pipiringos, Stratigraphic relations of the Navajo Sandstone to Middle Jurassic Formations, southern Utah and northem Arizona, U.S. Geol. Surv. Prof. Pap., 1035-B, B1B43, 1979.

Pipiringos, G. N., and R. B. O'Sullivan, Principal unconformities in Triassic and Jurassic rocks, westem interior United States-A preliminary survey, U.S. Geol. Surv. Prof. Pap., 1035-A, A1-A29, 1978. 
Philpotts, A. R., and A. Martello, Diabase feeder dikes for the Mesozoic basalts in southem New England, Am. J. Sci., 286, 105-126, 1986.

Poole, F. G., Steam directions in Triassic rocks of the Colorado Plateau, U.S. Geol. Surv. Prof. Pap., 424C, 129-141, 1961.

Prevot, M., and M. McWilliams, Paleomagnetic correlation of Newark Supergroup volcanics, Geology, 17, 1007-1010, 1989.

Puffer, J. H., D. O. Hurtubise, F. J. Geiger, and P. Lechler, Chemical composition and stratigraphic correlation of Mesozoic basal units of the Newark Basin, New Jersey, and the Hanford Basin, Connecticut: Summary, Geol. Soc. Am. Bull., 92, 155-159, 1981.

Purucker, M. E., D. P. Elston, and E. M. Shoemaker, Early acquisition of characteristic magnetization in redbeds of the Moenkop Formation (Triassic), Gray Mountains, Arizona, J. Geophys. Res. $85,997-1012,1980$.

Ratcliffe, N. M., Reinterpretation of the relationship of the westem extension of the Palisades sill to the lava flow at Ladentown. New York, based on new core data, in Studies of the Early Mesozoic Basins of the Eastem United States, edited by A. J. Froelich and G. R. Robinson, Jr., U.S. Geol. Surv. Bull., 1776, 113-134, 1988.

Reeve, S. C., Paleomagnetic studies of sedimentary rocks of Cambrian and Triassic age, Ph.D. thesis, 426 pp., Univ. of Tex. at Dallas, 1975.

Reeve, S. C., and C. E. Helsley, Magnetic reversal sequence in the upper portion of the Chinle Formation, Montoya, New Mexico. Geol. Soc. Am. Bull., 83, 3795-3812, 1972.

Roberston, W. A., Manicouagan, Quebec, paleomagnetic results, Can. J. Earth Sci., 4, 641-649, 1967.

Sales, J. K., Crustal mechanics of Cordilleran foreland deformationA regional and scale-model approach, Am. Assoc. Pet. Geol. Bull., 52, 2016-2044, 1968.

Seidemann, D. E., Age of the Triassic/Jurassic boundary: A view from the Harford Basin, Am. J. Sci., 289, 553-562, 1989.

Seidemann, D. E., D. W. Masterson, M. P. Dowling, and K. K. Turekian, $\mathrm{K}-\mathrm{Ar}$ dates and ${ }^{40} \mathrm{Ar} /{ }^{39} \mathrm{Ar}$ age spectra for Mesozoic basalt flows of the Hartford Basin. Connecticut, and the Newark Basin, New Jersey, Geol. Soc. Am. Bull., 95, 594-598, 1984.

Shive, P. N., M. B. Steiner, and D. T. Huycke, Magnetostratigraphy, paleomagnetism and remanence acquisition in the Triassic Chugwater Group of Wyoming, J. Geophys. Res., 89, 1801-1815, 1984.

Smith, T. E., and H. C. Noltimier, Paleomagnetism of the Newark trend igneous rocks of the north central Appalachians and the opening of the central Atlantic Ocean, Am. J. Sci., 279, 778807. 1979.

Smith, W. A., Paleomagnetic results from a crosscutting system of northwest and north-south trending diabase dikes in the North Carolina Piedmont, Tectonophysics, 136, 137-150, 1987.

Steiner, M. B., Rotation of the Colorado Plateau, Tectonics, 5, 649660,1986
Steiner, M. B., Paleomagnetism of the late Pennsylvanian and Permian: A test of the rotation of the Colorado Plateau, $J$. Geophys. Res., 93, 2201-2215, 1988.

Steiner, M. B., and C. E. Helsley, Magnetic polarity sequence of the Upper Triassic Kayenta Formation, Geology, 2, 191-194, 1974.

Steiner, M. B., S. Lawerence, and M. E. Beck, Jr., A Jurassic pole position from the craton of North America (abstract), Eos Trans. $A G U, 69$, additional abstract, 1988.

Stewar, J. H., F. G. Poole, and R. F. Wilson, Stratigraphy and origin of the Chinle Formation and related Upper Triassic strata in the Colorado Plateau region, U.S. Geol. Surv. Prof. Pap., 690, 336 pp., 1972.

Sutter, J. F., Innovative approaches to the dating of igneous events in the early Mesozoic basins of the eastem United States, in Studies of the Early Mesozoic Basins of the Eastern United States, edited by A.J. Froelich and G. R. Robinson, Jr., U.S. Geol. Surv. Bull., 1776, 194-199, 1988.

Van Alstine, D. R., and J. DeBoer, A new technique for constructing apparent polar wander paths and the revised Phanerozoic path for North America, Geology, 6, 137-139, 1978.

Van der Voo, R., and K. L. Grubbs, Paleomagnetism of the Triassic Chugwater redbeds revisited (Wyoming, U.S.A.), Tectonophysics, 41, T27-T33, 1977.

Van Fossen, M. C., J. J. Flynn, and R. D. Forsythe, Paleomagnetism of Early Jurassic rocks, Watchung Mountaines, Newark Basin: Evidence for complex rotations along the Border fault, Geophys. Res. Letl., 13, 185-188, 1986.

Witte, W. K., and D. V. Kent, A middle Camian to early Norian $(\sim 225$ Ma) paleopole from sediments of the Newark Basin, Pennsylvania, Geol. Soc. Am. Bull., 101, 1118-1126. 1989a.

Witte, W. K., and D. V. Kent, Remagnetization of Newark Basin sediments: Implications for APW (abstract), Eos Trans. AGU, $70,311,1989 b$

Witte, W. K., and D. V. Kent, The paleomagnetism of red beds and basalts of the Hettangian extrusive zone, Newark Basin, New Jersey, J. Geophys. Res., 95, 17,533-17,545, 1990.

Wolfe, S. H., Potassium-argon ages of the Manicouagan-Mushalagan Lake structure, J. Geophys. Res., 76, 5424-5436, 1971.

Wu, F., and R. Van der Voo. Paleomagnetism of Middle-Late Triassic plutons in southem Maine, Tectonophysics, 156, 51-58, 1988.

Ziegler, A. M., C. R. Scotese, and S. F. Barrett, Mesozoic and Cenozoic paleogeographic maps, in Tidal Friction and the Earth's Rotation II, edited by P. Borsche and J. Sundermann, pp. 240252, Springer-Verlag, New York, 1983.

D. R. Bazard and R. F. Butler, Department of Geosciences, University of Arizona, Tucson, AZ 85721

(Received August 9, 1990;

revised January 2, 1991:

accepted January 28, 1991.) 